\title{
They Are What You Eat: Can Nutritional Factors during Gestation and Early Infancy Modulate the Neonatal Immune Response?
}

\author{
Sarah Prentice* \\ Clinical Research Department, London School of Hygiene and Tropical Medicine, London, United Kingdom
}

The ontogeny of the human immune system is sensitive to nutrition even in the very early embryo, with both deficiency and excess of macro- and micronutrients being potentially detrimental. Neonates are particularly vulnerable to infectious disease due to the immaturity of the immune system and modulation of nutritional immunity may play a role in this sensitivity. This review examines whether nutrition around the time of conception,

OPEN ACCESS

Edited by:

Kirsty Le Doare,

Imperial College London,

United Kingdom

Reviewed by:

Daniel Munblit,

Imperial College London,

United Kingdom

Stephen M. Todryk,

Northumbria University,

United Kingdom

*Correspondence:

Sarah Prentice

sarah.prentice@/shtm.ac.uk

Specialty section:

This article was submitted to

Vaccines and Molecular

Therapeutics,

a section of the journal

Frontiers in Immunology

Received: 31 August 2017

Accepted: 09 November 2017

Published: 28 November 2017

Citation:

Prentice S (2017) They Are What You

Eat: Can Nutritional Factors during

Gestation and Early Infancy Modulate

the Neonatal Immune Response?

Front. Immunol. 8:1641.

doi: 10.3389/fimmu.2017.01641 throughout pregnancy, and in early neonatal life may impact on the developing infant immune system.

Keywords: nutrients, immunity, ontogeny, neonatal, pregnancy, infection, supplements

\section{INTRODUCTION}

Nearly 3 million deaths occur annually in children less than 30 days old, principally in low and middle-income countries (1). Improvements in neonatal mortality rate have proved difficult to achieve. Low-cost, easily implementable interventions are urgently needed.

Infections directly account for approximately one-third of neonatal deaths and are likely to contribute to deaths from other causes such as prematurity and in cases where babies are stillborn (1). Neonates show heightened susceptibility to infectious diseases due to a functionally immature immune system (2). Innate immune components are compromised by impaired mucosal surface integrity (3), lower levels of complement proteins (4), and reduced phagocytic capacities (5). Adaptive immune responses to pathogens are attenuated compared to adult responses, with children under 2 months old tending toward more regulatory responses with strong Th- 2 and Th-17 cell polarization and weak Th-1 polarization $(2,6,7)$. This is partly necessary to produce a tolerogenic environment, stopping rejection at the maternofetal interface and reducing reactions to self-antigens, and partly due to lack of primary exposure to antigens necessary to build up the adaptive immune responses. This functional immaturity of responses leaves the neonate particularly vulnerable to infectious pathogens. Decades worth of research has been directed at identifying interventions to improve neonatal immune responses to infections.

Various organs are sensitive to nutrition during embryonic and fetal development. Nutritional status can have short-term impacts on both fetal and childhood growth and development and longer term influences on adult health. Infants born following periods of nutritional deprivation, such as the Dutch Hunger Winter and identified in The Hertfordshire cohort, show increased risks of coronary heart disease, stroke, type- 2 diabetes and metabolic syndrome when subsequently exposed to periods of nutrient sufficiency $(8,9)$. The concept that undernutrition during gestation may contribute to adult disease by having permanent effects on the structure, function and metabolism of 
the developing fetus, is known as the Developmental Origins of Health and Disease (DOHaD) theory. It has subsequently been shown to extend to a range of other diseases including psychiatric illnesses and cancers (10). Excess macronutrient consumption in mothers has also been associated with long-term sequelae in their offspring (11). Micronutrient deficiencies have long been known to have impacts on organogenesis, with iodine deficiency leading to congenital hypothyroidism (12) and folate deficiency increasing the risk of neural tube defects (13). Therefore, it has been hypothesized that the developing immune system is likely to be similarly sensitive to nutrition and that optimizing a mother's nutritional state during pregnancy will have long-term benefits for the immune responses during the neonatal period and beyond.

Early human evidence that nutritional factors during gestation might specifically influence adult immune responses came from longitudinal studies carried out in The Gambia in the 1990s (14). The Gambia has a strong bimodal seasonality that has major effects on the nutritional status of the population. The dry season, running from November to June, is a time of relative nutrient security. With the previous seasons crops being harvested, macronutrients are in greater supply and manual labor levels tend to be lower. In contrast, the rainy season, running from July to October, is characterized by declining levels of food availability and higher manual labor demands as the next season's crops are planted but the previous seasons supply is running short. This leads to deficits of both energy and micronutrient intakes that are particularly pronounced for women, who bare the brunt of much of the agricultural work (15). Analysis of demographic surveillance data available for the population from the 1940s revealed that people born during the "hungry" rainy season had a threefold higher risk of mortality from infectious diseases as adults than those born during the dry season (14). These findings were independent of subsequent nutritional status, as demonstrated by anthropometric and hematological status at 18 months of age, suggesting that the effector of these changes occurred earlier on in development. These data suggested that environmental factors, most likely nutrition, during conception, gestation and early postnatal life can have marked effects on the immune system that are stable, durable and not susceptible to modification by later improvements in nutritional status.

Nutrient intake of the mother and neonate is theoretically amenable to modification via supplements, which represent lowcost, easily implementable public health interventions. As such, there has been huge interest in the provision of nutritional supplements during gestation and early infancy to improve neonatal outcomes. This review summarizes the evidence regarding the impact of early life nutrition on biochemical immune markers and clinical infectious diseases outcomes in neonates.

\section{POTENTIAL MECHANISMS FOR NUTRITIONAL INFLUENCES ON THE DEVELOPING NEONATAL IMMUNE SYSTEM}

Studies in older children and adults have demonstrated the important influence that different nutrients have on the immune system. These effects, and the impacts of deficiencies on susceptibility to infectious diseases, are summarized in Table 1. Although the influence of nutrients on the developing immune system in utero and in early neonatal life may be similar to that of older children and adults, the impact of the nutritional state of the mother on the neonatal immune system is less well described.

Mother's nutritional status may hypothetically affect the neonatal immune system by influencing:

- The mother's own immune system: Optimizing maternal nutrition could directly enhance the neonatal immune system by increasing the quality and quantity of antibody and other immune factors available for passive transfer across the placenta and in breast milk. It could also indirectly improve neonatal immunity, by reducing the likelihood of maternal infections that may lead to preterm birth, a known cause of IgG deficiency in neonates due to reduced third-trimester antibody transfer (57). Increased maternal infections may also influence neonatal immune development via effects on the hypothalamic-pituitary-adrenal (HPA) axis (see below).

- Placentation: Maternal nutrient availability has been shown in animal and human studies to affect placentation, with affects on size, morphology, nutrient transfer receptors and vascular flow (58-63). This may theoretically affect passive transfer of antibodies and other immune factors to the fetus as well as altering the efficiency of nutrient transfer for fetal immune system development.

- The maternal HPA axis: The HPA axis is activated in times of low nutrient availability [particularly protein-energy malnutrition (64) and zinc deficiency $(65,66)]$ leading to increased circulating glucocorticoids. Increased cortisol levels can lead to both immunosuppression and altered placental function in the mother, with downstream effects for the fetus as described above, as well as directly impacting on the fetal immune system via actions on its own HPA axis.

- The maternal gut microbiome: The human intestinal tract contains more than $10^{14}$ bacteria and other organisms (67). These commensal microflora have evolved a complex symbiotic relationship with humans, and are increasingly recognized as essential for many aspects of human health (68). Nutrient intake influences the composition of the gut microbiota, which in turn can influence the availability of nutrients for absorption from food (69-71). The gut microbiome is crucial for the development and functioning of the mucosal immune system (72). Healthy gut flora help to promote mucosal tolerance to non-pathogenic antigens, reduce the overgrowth of pathogenic microorganisms and enhance absorption of nutrients that are potentially important for systemic immune system development (68). Dysbiosis (altered microbiome) has been associated with increased risk of immune-mediated diseases such as allergy, asthma, and inflammatory bowel diseases, as well as increased risk of infections (73). Animal models suggest that the immune development of the offspring may be influenced by the maternal microbiota in the following ways [reviewed in detail in Ref (74)]: (1) alteration of nutrient uptake having direct effects on maternal immunity and hence the availability of antibodies and immune factors for transfer to the offspring, 
TABLE 1 | Nutrients and their effects on immunity.

\begin{tabular}{|c|c|c|c|}
\hline Nutrient & Effect on immunity & Effect of deficiency on clinical immune outcomes & Reference \\
\hline Protein energy & $\begin{array}{l}\text { Innate } \\
\text { Epithelial integrity } \\
\text { Complement levels } \\
\text { NK-cell activity } \\
\text { Adaptive } \\
\text { T-lymphocyte number and function, particularly Th1-type cytokines } \\
\text { Delayed type hypersensitivity } \\
\text { Effect on B-lymphocytes less clear }\end{array}$ & Increased bacterial, viral, and fungal infections & $(16,17)$ \\
\hline n-3 PUFAs & $\begin{array}{l}\text { Activity is largely immunosuppressant with reductions in: } \\
\text { Innate } \\
\text { Leukocyte chemotaxis and adhesion } \\
\text { NK-cell function } \\
\text { Innate cytokine production } \\
\text { Adaptive } \\
\text { T-lymphocyte signaling }\end{array}$ & $\begin{array}{l}\text { Theoretical increases in inflammatory-mediated diseases } \\
\text { and allergy. Trials suggest that supplementation reduces } \\
\text { the risks of inflammatory-mediated diseases such as } \\
\text { rheumatoid arthritis and improves responses to infectious } \\
\text { disease }\end{array}$ & $(18-25)$ \\
\hline Vitamin A & $\begin{array}{l}\text { Innate } \\
\text { Epithelial integrity } \\
\text { Neutrophil, monocyte, macrophage, and NK-cell number and function } \\
\text { Adaptive } \\
\text { T-lymphocyte differentiation and migration } \\
\text { T-lymphocyte numbers, especially CD4 } \\
\text { B-lymphocyte numbers } \\
\text { Antibody production and may affect the balance of production of different } \\
\text { IgG subclasses }\end{array}$ & $\begin{array}{l}\text { Increased susceptibility to infections, particularly diarrhea, } \\
\text { respiratory infections and measles. Supplementation } \\
\text { of children from } 6 \text { months to } 5 \text { years in areas at risk of } \\
\text { deficiency reduces all cause mortality, diarrhea incidence } \\
\text { and mortality and measles incidence and morbidity on } \\
\text { meta-analysis }\end{array}$ & $(26-28)$ \\
\hline B vitamins & $\begin{array}{l}\text { Vitamin B2 (riboflavin) } \\
\text { Phagocyte activation } \\
\text { Vitamin B6 } \\
\text { Dendritic cell function } \\
\text { Lymphocyte maturation and growth } \\
\text { T-lymphocyte activity and delayed type hypersensitivity } \\
\text { B-lymphocyte activity and antibody production } \\
\text { Vitamin B9 (folate) } \\
\text { Epithelial integrity } \\
\text { NK-cell activity } \\
\text { T-lymphocyte proliferation and response to mitogenic activation } \\
\text { Cytotoxic T-lymphocyte activity } \\
\text { Vitamin B12 } \\
\text { NK-cell activity } \\
\text { CD8+ T-cell activity } \\
\text { B-lymphocyte activity and antibody production }\end{array}$ & & $(29-39)$ \\
\hline Vitamin C & $\begin{array}{l}\text { Innate } \\
\text { Epithelial integrity } \\
\text { Phagocyte production } \\
\text { Antioxidative functions } \\
\text { Adaptive } \\
\text { T-lymphocyte maturation } \\
\text { Interferon production }\end{array}$ & $\begin{array}{l}\text { Association with increased incidence and severity of } \\
\text { pneumonia. Supplementation in the elderly shows } \\
\text { possible reductions in pneumonia incidence and duration }\end{array}$ & $(40)$ \\
\hline Vitamin D & $\begin{array}{l}\text { Innate } \\
\text { Macrophage activity (cathelecidin antimicrobial peptide expression, } \\
\text { induction of reactive oxygen intermediaries, activation of autophagy) } \\
\text { Adaptive } \\
\text { T-lymphocyte number and function } \\
\text { Th1/Th2 balance skewed to Th2 } \\
\text { Unclear effect on B-lymphocytes (in humans) }\end{array}$ & $\begin{array}{l}\text { Increased susceptibility to infections, particularly of the } \\
\text { respiratory tract. Meta-analysis shows reduced acute } \\
\text { respiratory tract infections when routine supplementation } \\
\text { is given in the context of deficiency }\end{array}$ & $(41-43)$ \\
\hline Vitamin E & $\begin{array}{l}\text { Innate } \\
\text { Epithelial barrier integrity } \\
\text { NK-cell activity } \\
\text { Adaptive } \\
\text { T-lymphocyte proliferation and function } \\
\text { Delayed type hypersensitivity reactions } \\
\text { Vaccine-mediated antibody responses }\end{array}$ & $\begin{array}{l}\text { Supplementation is suggested to lead to reduced } \\
\text { respiratory tract infections in the elderly }\end{array}$ & $(37,44,45)$ \\
\hline
\end{tabular}


TABLE 1 | Continued

\begin{tabular}{|c|c|c|c|}
\hline Nutrient & Effect on immunity & Effect of deficiency on clinical immune outcomes & Reference \\
\hline Zinc & $\begin{array}{l}\text { Innate } \\
\text { Epithelial barrier integrity } \\
\text { Proinflammatory cytokine production } \\
\text { Neutrophil oxidative burst } \\
\text { NK-cell function } \\
\text { Adaptive } \\
\text { T-cell maturation and proliferation } \\
\text { Th1/Th2 balance skewed to Th1 }\end{array}$ & $\begin{array}{l}\text { Increased bacterial, viral and fungal infections: particularly } \\
\text { diarrhea and pneumonia. Routine supplementation of } \\
\text { children in at-risk areas leads to reductions in duration } \\
\text { of diarrhea and incidence of pneumonia, in children } \\
>6 \text { months on meta-analysis, but not in children } \\
2-6 \text { months old }\end{array}$ & $(46-50)$ \\
\hline Selenium & $\begin{array}{l}\text { Adaptive } \\
\text { CD4+ T-lymphocyte proliferation and function }\end{array}$ & Increased viral virulence & $(51-54)$ \\
\hline Iron & $\begin{array}{l}\text { Innate } \\
\text { Neutrophil, NK-cell, and macrophage activity } \\
\text { Innate cytokine production } \\
\text { Adaptive } \\
\text { T-lymphocyte numbers } \\
\text { No apparent effect on B-lymphocyte number and function }\end{array}$ & $\begin{array}{l}\text { May enhance or protect from infections with } \\
\text { bacteria, viruses, fungi and protozoa depending on the } \\
\text { level of iron. Although supplementation may theoretically } \\
\text { enhance immunity to infectious diseases, untargeted } \\
\text { supplementation may increase availability of iron for } \\
\text { pathogen growth and virulence and increase susceptibility } \\
\text { to, particularly, malaria and bacterial sepsis }\end{array}$ & $(55,56)$ \\
\hline
\end{tabular}

(2) alteration of the repertoire of antibodies passively transferred to the neonate, which may alter the degree of mucosal tolerance in the neonate, and hence its own microbiome composition $(75,76)$, (3) bacterial metabolites derived from the microbiota may be transferred to offspring across the placenta and in breastmilk and may impact on the offspring's developing immune system (77), and (4) organisms from the maternal microbiota can be found in placental tissue (78) and this exposure may impact directly on the developing infant immune system and indirectly by altering gestational length.

The mother's nutritional status may also affect the neonatal immune system by directly altering the nutrients available to the developing embryo/fetus. This may theoretically have long-term effects on offspring immunity via:

- Epigenetic modification: Epigenetic modification is the process by which stable alterations to gene expression, and thus the phenotype of cells, are induced without changes to the primary DNA sequence $(79,80)$. These modifications may be altered in response to environmental factors, persist following cell division, and, in some cases, are heritable-providing a means by which the environment may have permanent and multigenerational impacts on phenotype (81). The three main types of epigenetic modification are (1) DNA methylation; where the degree of methylation at, primarily, $\mathrm{CPG}$ dinucleotide rich sites in gene-specific promoters affects the degree of expression of that gene, (2) histone modification; where the accessibility of promoter regions of genes to transcription machinery is altered by additions to protein tails, affecting the degree to which DNA transcription occurs, and (3) non-coding RNAs, where small lengths of RNA bind to target mRNA, altering its subsequent translation (81). Of these, DNA methylation has emerged as a strong candidate effector mechanism to explain the $\mathrm{DOHaD}$ theory as it largely occurs during embryogenesis or early postnatal life, and produces durable effects (82). Alterations in DNA methylation of key metabolic genes induced by famine exposure in early life persist for at least six decades $(83,84)$.
Epigenetic modification could theoretically have similar longterm impacts on the expression of genes important for the immune system.

- Organogenesis and lymphopoiesis: The process by which organs develop during embryonic and fetal life is highly sensitive to environmental influences. It has long been known that exposure to adverse factors at critical windows of organogenesis can lead to permanent changes in organ growth and function. Development of the infant immune system is likely to be similarly susceptible to environmental influences, including nutrient levels. In older children, both the thymus and hematopoietic branches of immunity are acutely sensitive to undernutrition, with reductions in thymus size and blood cell functioning shown to occur in both acute and chronic starvation conditions (85). As both immune compartments undergo massive expansion during the gestational period, with the thymus being at its largest as a proportion of body size at birth, it is highly plausible that nutritional conditions in utero would impact on the neonatal immune system. Studies in animals support a link between maternal macro/micronutrient deficiency and reduced thymic size and function (86-88), which may not be fully reversible by later improvements in nutrition (89).

- Immunoregulatory mechanisms, e.g., the neonatal HPA axis: Maternal cortisol levels (which may be altered by nutrient availability, see above), can influence the development of the fetal HPA axis, with long-term consequences for neuroendocrine-immune interactions $(90,91)$. Although the developing fetus is generally protected from maternal cortisol fluctuations by the function of $11 \mathrm{~B}$-hydroxysteroid dehydrogenase in the placenta, levels of this enzyme are decreased by undernutrition (92). Evidence from animal studies suggests that stimulation of the fetal HPA axis can lead to lower lymphocyte proliferation, reduced NK-cell activity, and reduced antibody responsiveness in offspring (93), as well as increasing the responsiveness of the HPA axis to stressors later in life. These effects are hypothesized to be mediated through epigenetic programming of glucocorticoid receptors (91). 
- The neonatal gut-microbiome: The neonatal gut microbiome is strongly influenced by the maternal microbiome. Colonization of the gastrointestinal tract occurs around the time of birth (and possibly even earlier) with organisms acquired from the mother's gastrointestinal tract, vagina, skin, and breast milk, and is influenced by delivery type, gestational age, and feeding method among other factors (94). Modification of the maternal microbiome may thus be hypothesized to influence the developing neonatal immune system both directly, by altering the neonatal microbiome composition, and indirectly, by altering the nutrient status of the mother and hence the availability of nutrients for immune system development during fetal life.

A conceptual framework for the potential influences of early life nutrition on the developing infant immune system is shown in Figure 1. Evidence for such effects occurring in humans is discussed below.

\section{EVIDENCE FOR THE INFLUENCE OF PRE- AND PERICONCEPTIONAL NUTRITION ON THE INFANT IMMUNE SYSTEM}

\section{Epigenetic Modification of the Early Embryo}

Specific evidence for the impact of periconceptional nutrition on later immune functioning through epigenetic modifications has been suggested from the previously described Gambian cohort. The plasma levels of 1-carbon metabolites crucial for DNA methylation undergo seasonal variations in pregnant women.
Higher levels of folate, methionine, and riboflavin, and reduced homocysteine levels occur in the nutritionally challenged rainy season (95-97). Although counterintuitive, this may be due to increased consumption of green leafy vegetables during this period, due to the need to food diversify (98). The increased level of these methyl-donor intermediaries correlates with increases in DNA methylation seen at metastable epialleles (MEs) (see Box 1) in children conceived in the rainy season (and thus born in the dry season, correlating with reduced later infectious disease mortality) $(96,99)$. A metastable epiallele VTRNA2-1, involved in tumor suppression and viral immunity, has been identified that is differentially methylated according to season of conception (and hence nutritional status), and is stable for at least 10 years (100). This provides the first in-human evidence that periconceptional nutrition could directly influence subsequent immune functioning. Although the clinical relevance of the variability in methylation of this ME in susceptibility to infections has yet to be proven, it provides a tantalizing suggestion that the seasonal variation in adult infectious disease mortality is mediated, at least in part, through nutritionally sensitive epigenetic modifications.

A number of epidemiological studies have now linked DNA methylation status at the promoter region of inflammatory mediators to nutritional status in pre- and early postnatal life (107-109), although the timing of nutritional influences causing these epigenetic modifications is difficult to prove. Methylation status of these genes has been correlated with later markers of biochemical inflammation, though effects on clinical outcomes have yet to be shown (107). Intriguingly, animal models have shown that alterations to paternal diet can alter DNA methylation in offspring, with resultant phenotypic changes increasing the risk of obesity and metabolic syndromes (110-113). The

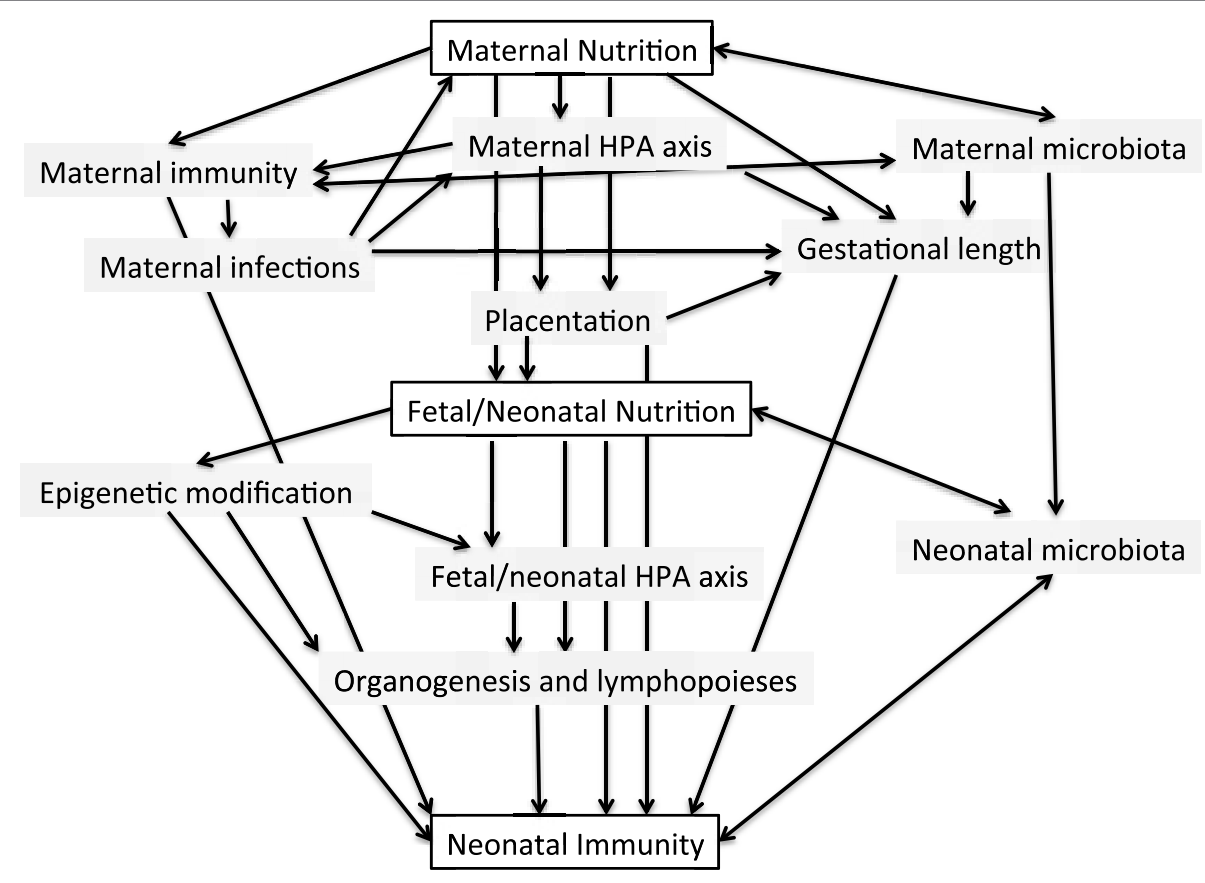

FIGURE 1 | Conceptual framework for the potential interactions between maternal and early neonatal nutrition and the developing infant immune system. 


\begin{abstract}
BOX 1 | Metastable epialleles. A tool for investigating the influence of the periconceptional environment on offspring epigenomes.

The inherent tissue specificity of many epigenetic changes creates challenges for the study of the influence of epigenetic modifications on adult phenotypes (99). While epidemiological association studies between gene variants and risk of disease may use easily obtainable peripheral blood draws, studies investigating epigenetic influences on disease etiology may require tissuespecific samples that are often not as accessible. Metastable epialleles (MEs) are regions of DNA where methylation is established stochastically in the early embryo and is subsequently maintained throughout all three germ-layer lineages (101). Thus, methylation of MEs occurring in the early embryonic period (pregastrulation) may be determined from peripheral blood samples.

Differential methylation of MEs in mice has been shown to have dramatic phenotypic consequences including alterations in fur color (102), tail-kinking $(4,103)$, and propensity to obesity (104). Methylation of murine MEs is strongly influenced by maternal nutrition and other environmental factors in the periconceptional period $(105,106)$. MEs in humans may have effects on adult disease and provide an easily accessible method of investigating the epigenetic pathways that may be involved in the $\mathrm{DOHaD}$ theory.
\end{abstract}

potential transgenerational influence of paternal diet on the health outcomes of offspring has also been suggested in humans from epidemiological studies carried out in Sweden. These showed a correlation between reduced food availability during the father's, and even grandfather's, preadolescence and increased life expectancy, with reduced risk of cardiovascular and diabetesrelated mortality (114). Other studies have linked early onset of paternal obesity with increased liver enzymes and long-term changes in percentage body fat in offspring. These effects are likely to be mediated by epigenetic modification of spermatozoa, and may be sex specific (115). Thus, it may be that paternal diet is also ultimately shown to produce lasting effects on the immune system of offspring.

Although most human studies have focused on DNA methylation as a mediator of long-term effects of periconceptional environment on the health of off-spring, animal studies suggest that histone modification $(116)$ and microRNAs $(117,118)$ may also play a role in the developmental origins of disease, though their importance in immune system development has yet to be investigated. Thus, it appears likely that immune system functioning is influenced by interacting and overlapping epigenetic modifications induced by nutritional status, and other environmental factors, occurring around the time of conception, during gestation and in early postnatal life.

\section{Placentation}

Although evidence for the importance of several micronutrients including vitamin $\mathrm{D}$, zinc, folate, calcium, and iron on placental growth and function exists $(58,59)$, studies directly investigating the effects of periconceptional maternal nutrition on placentation and subsequent fetal immunity are limited. One study that randomized non-pregnant women of child-bearing age to a multiplemicronutrient (MMN) supplementation or placebo and followed up subsequent pregnancies, showed minimal improvements in placental vascular function with MMN supplementation, but no improvements in other markers of placental function (plasminogen activation inhibitor 1 and 2 ratio) and transfer of maternal measles antibody at birth (119).

\section{EVIDENCE FOR THE INFLUENCE OF GESTATIONAL NUTRITION ON THE INFANT IMMUNE SYSTEM}

\section{Macronutrients}

\section{Protein Energy}

The relationship between maternal nutrition and fetal growth is complex, involving maternal metabolic and endocrine, as well as placental, functioning $(2,120)$. However, the neonatal presentation of protein-energy malnutrition is assumed to be infants who are born small-for-gestational age (SGA). Infants born SGA or low-birth weight (LBW) have an increased risk of infectious mortality in the neonatal period and beyond (121-124). SGA/LBW infants show altered immunology, with lower complement and IgG (125), lower plasmacytoid dendritic cells, higher NK-cells and higher IgM (126), and higher inflammatory activation and T-cell turnover (127), compared to those delivered at an appropriate weight. Gambian infants born in the nutritionally deprived rainy season (a presumptive marker of reduced macronutrient supply in late gestation) show smaller neonatal thymus size (128), and have some changes to thymic function (129). These immune changes do not appear to be long lasting, however, and a seasonal effect of infectious disease incidence may contribute to these findings $(130,131)$. Intrauterine growth restriction has been associated with reduced vaccine responses in childhood, though inconsistently (132-135).

Given the suggested link between macronutrient deficiencies and neonatal morbidity, a number of maternal protein supplementation strategies have been evaluated (136). Balanced protein energy supplementation (containing up to 20\% of energy as protein) leads to modest increases in birth weight (up to $324 \mathrm{~g}$ ) (137), and reduces the number of SGA infants born by around a third (136). Reductions in neonatal deaths as a result of supplementation have not been clearly shown, however, with meta-analysis of the three published studies reporting neonatal mortality showing only non-significant improvements in neonatal outcomes $(136,138-140)$. Even if these non-significant reductions in mortality are true findings, the causal mechanisms underlying such effects are unknown, with reductions in prematurity likely to play a significant role. No clear link between maternal protein energy supplementation and improvement in neonatal immunity has been demonstrated. Maternal protein supplementation has no proven impact on later vaccine responses, mucosal immunity and delayed-type hypersensitivity reactions (130) or thymus size (141), although impacts on thymic function at the cellular level were not assessed. The lack of substantial demonstrable neonatal benefits from maternal protein energy supplementation may reflect the heterogeneous etiologies of SGA and LBW, with factors such as poor placentation and environmental toxin exposure not addressed by supplementation. It may also be due to challenges with targeting the intervention to the most at-risk subjects within populations. Subgroup analysis of supplementation studies suggest that the intervention is only beneficial when provided to malnourished individuals, and that high protein supplements may even impair fetal growth when given in the context of adequate diets (136). 


\section{Lipids}

Maternal PUFA supplementation during gestation is associated with reductions in preterm births and small increases in birth weight (142) on systematic review. However, impacts on the immune system are less clear. Most research has been directed on the effect of fish-oil supplementation on reduction in atopy risk in offspring. Systematic reviews have suggested reductions in offspring IgE-mediated allergy and eczema following gestational/ lactational n-3 PUFA supplementation, though the duration of these effects is not clear and the relative importance of the timing of supplementation during gestation or lactation is difficult to determine $(143,144)$. Murine studies suggest that n-3 PUFA supplementation of mothers can improve offspring responses to infections, with enhanced vaccination responses shown in mice fed high n-3 PUFA diets during gestation and lactation (145). In humans, docosahexaenoic acid (DHA) supplementation during gestation and lactation was associated with reductions in CD8+ $\mathrm{T}$-cells, increases in naive CD4CD45RA+ helper cells and reductions in lymphocyte IFN $\gamma$ production (146). However, this trial did not show changes to immunoglobulin levels, vaccination responses or clinical outcomes and may have been confounded by the high baseline dietary DHA levels of all participants. One trial of prenatal DHA supplementation has shown reduction in incidence and duration of cold symptoms during infancy (147). No significant evidence of reductions in neonatal outcomes such as sepsis, morbidity or mortality have been shown in systematic review of human studies, though adequately powered trials to assess these outcomes are lacking (148).

\section{Micronutrients}

Micronutrient deficiencies are estimated to affect approximately 2 billion people worldwide. They are often particularly severe in women of reproductive age due to the high demands of pregnancy and lactation (149). Optimization of micronutrient levels in pregnant women has therefore been proposed as a strategy to enhance neonatal immunity.

\section{Specific Micronutrient Supplementation during Gestation \\ Zinc}

Overt zinc deficiency is now rare but moderate deficiency is common worldwide (150). Zinc supplementation of mothers leads to biochemical improvements in their zinc status and that of their offspring $(151,152)$. Thymus size in infants correlates with cord-blood zinc levels (153), although a recent study showed no impact of maternal zinc supplementation on infant thymic size (154). Improved hepatitis B vaccine antibody responses and delayed type hypersensitivity reactions to BCG vaccination have been shown following maternal zinc supplementation (154), but no effect on haemophilus influenza $\mathrm{B}$ conjugate vaccine responses has been found (155). Theses studies suggest some influence of maternal zinc supplementation on infant immune development, but the clinical impact of this is uncertain. A recent systematic review of 21 trials $(>17,000$ mother-infant dyads) suggests no benefit of maternal zinc supplementation for IUGR, LBW, stillbirth, and neonatal death, though small reductions in preterm birth were shown (156). No significant reduction in neonatal infective outcomes, including neonatal sepsis, umbilical infections, fever, and necrotizing enterocolitis (NEC), was seen but the number of studies reporting these outcomes was small. One study from Bangladesh showed reduced acute diarrheal and impetigo episodes in the first 6 months of life following maternal zinc supplementation, though no difference in persistent diarrhea, cough, and LRTI $(157,158)$. A study from Indonesia similarly reported reduced diarrheal incidence in infants $<6$ months old following maternal supplementation with zinc, but this was at the expense of increased episodes of cough (159). Conversely, a study in Peru did not report any benefit for diarrheal prevalence (160).

\section{Vitamin D}

Vitamin D deficiency is common worldwide due to lack of UV exposure in northern latitudes, darker skin pigmentation in southern latitudes, covering the skin with clothes, and vegetarian diets. There are strong correlations between maternal and umbilical cord vitamin D with deficiency or insufficiency in the mother likely to cause deficiency in offspring (161). Systematic reviews of supplementation in pregnancy suggest reduced risk of vitamin $\mathrm{D}$ deficiency in offspring and slight increases in birth weight $(162,163)$. However, no evidence for improvement in any other neonatal outcomes including neonatal mortality has been shown (162). Impacts of vitamin D deficiency on the developing immune system have been shown with reduced thymus size in offspring (164) and an association with increased CRP [although this trend is reversed with vitamin D sufficiency $(>50 \mathrm{nmol} / \mathrm{L})(165,166)]$. Maternal vitamin $\mathrm{D}$ supplementation during gestation results in increased Th1 and Th2 cytokine gene expression and reduced pattern recognition receptor expression in cord blood, following stimulation with PHA (167). Clinically, vitamin D deficiency in cord blood has been associated with increased risk of lower respiratory tract infections, wheeze, and eczema in a number of observational studies, suggesting long-term impacts on immune ontogeny, although causation is difficult to prove $(168,169)$. Of four studies assessing the impact of maternal vitamin D supplementation on infant risk of respiratory infections and wheeze (170-173), only one showed significant reductions in incidence of acute respiratory tract infections in offspring (170). In this study the intervention was combined with postnatal vitamin $\mathrm{D}$ supplements so the contribution of maternal supplementation per se is difficult to assess. A recent systematic review of vitamin $\mathrm{D}$ supplementation in pregnancy and early life did not show any reduction in the risk of persistent wheeze, eczema, or asthma, though the quality of available evidence was low (174).

\section{Vitamin A}

Vitamin A deficiency is associated with increased susceptibility particularly to diarrhea, respiratory infections, and measles (27). Infants born to mothers with low serum retinol had increased all-cause neonatal mortality in a study in Malawi (175). Nepali infants born to mothers with xeropthalmia (the clinical manifestation of severe vitamin A deficiency) had a $63 \%$ increased mortality within the first 6 months of life, which was reduced following maternal supplementation (176). However, large randomized controlled trials of vitamin A supplementation 
including more than 310,000 mother-infant pairs have failed to show benefits for perinatal and all-cause neonatal mortality on systematic review, despite reductions in maternal nightblindness and possible reductions in maternal infections (177). There is some evidence, though, that vitamin A supplementation of women may lead to long-term enhancement of natural antibody levels in offspring, perhaps acting through impacts on early lymphopoiesis (178). This suggests that long-term alterations to the neonatal immune system may occur following vitamin A supplementation, but that more sensitive outcome measures are required to identify these changes than all-cause neonatal mortality.

\section{Iron}

Fetal iron acquisition occurs actively across the placenta, mainly in the last trimester of pregnancy, and is highly regulated (179, 180). Direct correlations between maternal and fetal iron status are not consistently seen, as neonatal iron levels are likely to be preserved at the expense of maternal stores, but severe maternal anemia is associated with reductions in neonatal iron (181). Iron deficiency is thought to be the most prevalent micronutrient deficiency worldwide (182). It occurs particularly in low-income countries where diets tend to be low in absorbable iron and parasitic burden can be high. Systematic reviews support the use of daily or intermittent iron supplementation during pregnancy for improvement of maternal iron status and reduction in anemia $(182,183)$. However, no evidence for improvements in other maternal or neonatal outcomes has been found. There is a current paucity of evidence regarding specific impacts, whether beneficial or detrimental, of maternal oral iron supplementation on neonatal infection risks (184). Similarly, studies investigating a direct impact of fetal iron status on immune system ontogeny are lacking.

\section{B-Vitamins, Including Folic Acid}

Folate (vitamin B9) has been widely studied as a pregnancy supplement, due to its role in the reduction of neural-tube defects. A systematic review of 31 studies, mainly carried out in Europe in the 1960s and 1970s, showed a modest increase in birth weight (136 g) following maternal folate supplementation, but no reduction in preterm birth, still-birth, or neonatal death (all cause) (185). The impact of folate supplementation in pregnancy on neonatal immune parameters and infective outcomes has not been investigated. More recently, concerns have been raised that folate supplementation given beyond the first trimester, or in excessive doses during pregnancy, may be linked to an increased risk of allergy/asthma, but the evidence is largely from observational studies and is not yet conclusive (186).

Vitamin B12 deficiency is associated with an increased risk of preterm birth (187), but its supplementation in pregnancy has been little studied. One study in Bangladesh confirmed that maternal oral vitamin B12 supplementation during pregnancy and lactation led to significant increases in infant B12 levels, but this was not associated with improvements in passive transfer of influenza antibodies or levels of acute inflammation markers (188). A significant reduction in number of infants with raised CRP was shown, but the number of infants with the outcome was small and the influence of timing of supplementation during pregnancy or lactation could not be distinguished.

A systematic review of three randomized controlled trials of maternal supplementation with vitamin B6 has been shown to result in a significant reduction in mean birth weight (217 g) (189). The impact of supplementation on neonatal mortality or infections has not been studied (190).

One study of vitamin B2 supplementation during pregnancy and lactation exists, which showed modest increases in infant riboflavin levels, but did not report neonatal outcomes (191). Sole supplementation with other B-vitamins has not been studied in the context of pregnancy and their impacts on the developing neonatal immune system are unknown.

\section{Other Vitamins and Trace Elements}

A number of other micronutrients with known immunomodulatory effects in adults have been little studied in neonates. Longitudinal studies of the influence of maternal diet on infant respiratory outcomes have suggested inverse associations between maternal vitamin E intake and infant asthma/wheeze (192-194), however, this has not been borne out in randomized controlled trials of maternal supplementation (195). Maternal selenium deficiency leads to low selenium status of neonates and is associated with reduced circulating adaptive immune cells and in vitro thymocyte activation (196). Observational studies have associated maternal selenium deficiency with enhanced risk of infant infections in the first 6 weeks of life, but these studies are at high risk of confounding (197). One supplementation study of selenium in HIV positive mothers showed a possible reduced risk of all-cause child mortality after 6 weeks of life, but a non-significant increase in fetal deaths (198). No studies have yet investigated maternal vitamin $\mathrm{C}$, vitamin $\mathrm{E}$, or selenium supplementation for neonatal immune outcomes specifically. There is also no current evidence for reductions in the more gross markers that may be associated with neonatal immune function (IUGR, LBW, preterm birth, perinatal, or neonatal death) from supplementation in pregnancy of vitamin C (199), vitamin E (200), copper (201), or selenium (198).

\section{Multiple Micronutrient Supplementation during Gestation}

When micronutrient deficiencies exist they are often multiple, due to poor quantity and diversity of available foodstuffs (149). Identification and targeted treatment of specific deficiencies in pregnant women is expensive and programmatically challenging. Therefore many studies aiming to enhance micronutrient levels in pregnancy use multiple micronutrient (MMN) supplements that provide the recommended daily allowance of all vitamins and minerals in one tablet (202). However, the evidence supporting the use of MMNs for neonatal outcomes in general, and neonatal immunity specifically is not clear. Meta-analysis of studies involving more than 135,000 women showed modest increase in birth weight (22-54 g), with corresponding reduction in babies born SGA or LBW, following MMN supplementation compared to standard iron and folic acid supplementation (203). These improved birth outcomes did not translate into improvements in neonatal and infant morbidity/mortality including from 
infectious disease (204). No MMN supplementation studies to date have investigated neonatal immune parameters specifically, although one randomized controlled trial from The Gambia is due to report shortly (205).

\section{Probiotics, Prebiotics, and Synbiotics}

Studies of maternal supplementation with probiotics (live microorganisms that contribute to a "healthy" gut microbiota), prebiotics [nutrients that promote growth of healthy bacteria, such as non-digestible oligosaccharides (206)], and synbiotics (a combination or pro- and prebiotics), for modulation of the neonatal immune system have been conducted in humans, but are relatively limited. A number of randomized controlled trials have shown that maternal consumption of probiotics or synbiotics can lead to measurable changes in the composition of their offspring's microbiome (207-210) and to changes in immune markers in the mother (211). However, alterations in infant immune markers following maternal supplementation, such as vaccine responses and cytokine levels, have been harder to show (212). Reduced incidence of eczema, though not asthma and wheeze, in infants has been suggested from systematic reviews of trials of prenatal supplementation but the effects may not be durable (72,213-216). One small trial has shown reduced gastrointestinal infections in infants born to mothers supplemented with probiotics (211), and another a reduction in respiratory infections (217), but these findings need to be confirmed in larger studies.

\section{EVIDENCE FOR THE INFLUENCE OF EARLY POSTNATAL NUTRITION ON THE INFANT IMMUNE SYSTEM}

The major nutritional influence on neonatal immunity is breast milk, which contains immunological components such as antibodies, anti-inflammatory cytokines and other antimicrobial factors, as well as the macro and micronutrients to support neonatal immune system development (218). Its benefits over formula milk for protection against various infections, atopy, and allergy are well reviewed elsewhere $(219,220)$. Here, we focus on the potential impact of supplementary nutritional interventions for the breastfeeding mother and neonate on the developing neonatal immune system.

\section{Lactational Supplementation}

The composition of breast milk is highly regulated according to the neonate's needs with the concentrations of many components maintained independently of maternal nutritional status and diet (221). Some immunomodulatory micronutrients, such as iron, folate and zinc $(222,223)$ and macronutrients such as arachadonic acid $(224,225)$ are not altered in the breast milk according to maternal diet. Therefore, maternal supplementation of these nutrients would likely have little or no impact on neonatal immune outcomes and they are not discussed further in this section. However, some immunoactive nutrients in breast milk are impacted by diet and their concentrations in milk vary worldwide. These include vitamin A, vitamin D, B vitamins, selenium, and PUFAs, particularly DHA $(34,221)$.

\section{Micronutrient Supplementation of Lactating Mothers Vitamin A}

Vitamin A is not only necessary for the developing neonatal immune system, its presence in breast milk is also important for the regulation of a number of breast milk proteins important for host defense (226). Infants are born with low vitamin A stores in the liver, and breast milk is the main source of vitamin A for infants during the first 6 months of life (227). Numerous reports have shown decreased breast milk vitamin A concentration with maternal deficiency, and increased concentrations with high exogenous vitamin A levels $(228,229)$. However, the results of postnatal maternal vitamin A supplementation studies for neonatal outcomes have been inconclusive. Systematic reviews of both lower dose (200,000 IU) and higher dose (400,000 IU) postpartum maternal vitamin A supplementation have shown only small increases in breast milk retinol concentrations (230) and a lack of supporting evidence for reduced infant morbidity (including from infections) to 6 months of age $(230,231)$. As a result, WHO no longer recommends routine postpartum vitamin A supplementation for women in low- and middle-income countries (WHO 2017). Studies on the effects of postpartum vitamin A supplementation on immunological outcomes specifically are limited and inconclusive. Studies variously report increases and no change to sIgA following postpartum vitamin A supplementation (226, 232). Further studies looking at a wider array of immunological parameters, and altering the timing of vitamin A supplementation are ongoing (226).

\section{Vitamin D}

Vitamin D deficiency is relatively common in breastfed infants, with low concentrations in milk even from vitamin D sufficient mothers (233). Studies investigating maternal postpartum supplementation have shown variable results, though on balance suggest supplementation may enhance infant vitamin D status (234-238). At present, however, direct neonatal supplementation of with vitamin $\mathrm{D}$ is the preferred method of enhancing neonatal vitamin D status (see below). Studies investigating the impact of vitamin D supplementation in breast-feeding women for neonatal immunological outcomes are lacking.

\section{B-Vitamins}

B-vitamins levels in the breast milk are largely amenable to improvements with supplementation of the mother (with the exception of folate) $(34,239)$, but there are no studies looking at the impact of lactational B-vitamin supplementation on neonatal immune outcomes.

\section{Selenium}

Selenium levels in breast milk are sensitive to dietary intake (240) and can be increased by supplementation $(240,241)$ [although these effects have not been consistently shown $(197,242)]$ and alter infant selenium status (243). Although selenium deficiency in infants has been associated with increased risk of respiratory infections in the first 6 weeks of life (197), large studies investigating maternal postpartum selenium supplementation for infant infectious morbidity have not been conducted. 


\section{Multiple Micronutrients}

Given the high prevalence of coexisting micronutrient deficiencies world-wide, there is a surprising lack of studies investigating the impact of multiple micronutrient supplements in breastfeeding mothers for infant outcomes (34). Only two small trials (52 women total) have compared MMN supplementation with nothing/placebo in breast feeding mothers, and reported on neither infant morbidity nor immunological outcomes $(34,232)$.

\section{Lipid Supplementation of Lactating Mothers}

The concentration of PUFAs, particularly DHA, in breast milk is highly affected by maternal diet (244), and PUFA supplementation increases levels in breast milk (245). Breast milk n3:n6 ratios have been associated with risk of allergy and atopy in infants in observational studies (246-248) although not consistently (249). Fish oil supplements provided during lactation alter cytokine production in the infant for at least 2.5 years, favoring faster immune maturation and Th1 polarization (250). Given the increasing existence of imbalanced n3:n6 ratios in westernized diets, there has been interest in providing PUFA supplements to lactating women for allergy prevention in infants, although concerns exist about potential negative impacts on infectious disease susceptibility $(251,252)$. However, at present only two studies (667 participants) have investigated postnatal maternal PUFA supplementation specifically, and although persisting alterations in cytokines have been shown, the studies were underpowered to detect differences in infant atopic disease or infectious morbidity $(143,250)$.

\section{Probiotic, Prebiotic, and Synbiotic Supplementation of Lactating Mothers}

Supplementation of lactating mothers with probiotics has been associated with alterations to breast milk cytokines and infant fecal IgA (253), and changes to the breast milk and infant microbiomes (254). Studies supplementing mothers with probiotics during lactation suggest a reduced risk of dermatitis, but interventions tended to combine pre- and postnatal supplementation, so the specific impact of lactational supplementation is difficult to determine (255). As with prenatal maternal supplementation, effects on infant immune outcomes following lactational supplementation require further evaluation $(72,256)$.

\section{Neonatal Supplementation}

Direct supplementation with crucial nutrients in the neonatal period has also been assessed as a strategy to protect infants from deficiency. However, in the majority of cases, despite improvements in the nutrient status of infants, no clear evidence for improvements in clinical or biochemical immune outcomes has been shown.

\section{Micronutrient Supplementation of the Neonate Zinc}

Zinc use in older infants has been associated with reductions in diarrhea duration (48) and lower respiratory tract infections incidence (47), but results following supplementation in the neonatal period have been more equivocal (257-261). One small study of zinc supplementation as an adjunct to antibiotics in neonates with sepsis showed a reduction in treatment failures and a non-significant $43 \%$ reduction in mortality (262). A larger study to investigate this is currently ongoing (263). Studies directly investigating the impact of neonatal zinc supplementation on immunological markers are limited. Routine zinc supplementation has not been associated with improvements in OPV seroconversion rates (264), although its use as an adjunct to antibiotics in neonatal sepsis has been associated with significantly reduced serum calprotectin, IL-6, and TNF $\alpha$ and a non-significant reduction in mortality (265).

\section{Vitamin D}

Vitamin D supplementation is recommended routinely in many countries for its impact on calcium and bone metabolism, but large-scale evidence for postnatal supplementation on any immunological disease outcomes (infection or allergy) is lacking (266). A recent systematic review of supplementation in children below 5 years of age did not show reductions in diarrhea and pneumonia incidence despite raised vitamin D levels in supplemented children, though supplementation in the neonatal period was not looked at specifically (42). One trial of maternal and infant vitamin D supplementation has suggested lower numbers of respiratory infection primary care visits following high dose maternal and infant supplementation, compared to low dose (170). A large trial to investigate immunological outcomes following neonatal vitamin D supplementation in breastfed infants is currently underway (266).

\section{Vitamin A}

Vitamin A supplementation in children from low- and middleincome countries aged 6 months to 5 years is associated with reductions in all-cause mortality of around one-third on systematic review (28). In contrast, a large systematic review of trials including more than 168,000 infants from low- and middle-income countries did not show any benefit of vitamin A supplementation when given in the neonatal period (267). Effects of supplementation may differ by underlying vitamin A status of the population, as reductions in all-cause mortality were suggested in the South Asian studies but not in the African studies. The African studies also showed concerning side-effects with increased transient bulging of the fontanelle and interactions of vitamin A with routine immunizations, particularly in female infants $(268,269)$. Studies investigating the effects of neonatal vitamin A on immunological parameters are limited. One study conducted in Guinea Bissau showed no effect of neonatal vitamin A supplementation on BCG vaccination responses at 6 months of age (270), although some evidence of reduced TNF $\alpha$ and IL-10 production in girls who have not received DTP vaccination (271). Two RCTs are currently ongoing to specifically investigate the effects of neonatal vitamin A supplementation on the immune system, but these have yet to report $(226,272)$. Routine vitamin A supplementation in children below 6 months of age is not currently recommended.

\section{Iron}

The provision of iron supplements to neonates deserves special mention due to its potential for increasing susceptibility to 
infections by enhancing iron availability for pathogens (55). Studies conducted in the 1970s showed that injecting neonates with iron dextran at birth significantly increased the risk of Escherichia coli meningitis and sepsis (273) and enhanced in vitro bacterial growth $(274,275)$. This may have been partly due to the mode of delivery, as parenteral iron administration is not subject to regulated uptake in the gut and therefore may overwhelm iron homeostatic mechanisms in iron replete children, but similar concerns exist with the untargeted provision of oral iron supplements. Older children given iron supplements from 4 months of age have increased risk of gastrointestinal infections (276), adult studies show increased in vitro bacterial growth in serum after oral iron supplementation (277) and there are suggestions that malaria risk is increased when oral iron is provided to iron replete children in endemic countries $(55,278)$. Human breast milk contains low levels of iron and has specific iron chelating agents such as lactoferrin. Our group and others have also shown that serum iron drops rapidly and profoundly in the first $12 \mathrm{~h}$ of life that and persists at low levels for at least 4 days. This low serum iron is associated with reduced ex vivo bacterial growth $(279,280)$. Taken together, this evidence suggests that humans may have evolved to mitigate against the enhanced pathogen susceptibility and oxidative stress that results from high iron loads. Therefore provision of exogenous iron to the neonate, except in specific situations where severe iron deficiency anemia has been diagnosed, may do more harm than good. In fact, there is increasing interest in novel therapeutics, such as lactoferrin and hepcidin agonists, that reduce serum iron in the context of neonatal infections (281-283). However, as preterm and growth-restricted infants have lower iron stores from birth, routine iron supplementation is often given, starting from 4 weeks of age, in high-income countries (284). In these settings, where infectious disease burden is low, no adverse infective outcomes have been shown on systematic review (285).

\section{Other Vitamins and Trace Elements}

Parenteral selenium supplementation of very LBW infants in NICU has been shown to increase selenium levels and reduce the incidence of neonatal sepsis, but systematic review of available evidence does not show improvements in survival $(286,287)$. No similar studies of oral supplementation in normal weight, term, breastfed infants in areas of selenium deficiency have been conducted. Studies looking at the effects of neonatal selenium, B-complex vitamins, vitamins $\mathrm{C}$ and $\mathrm{E}$, or combined micronutrient supplements on immunological parameters specifically are lacking.

\section{Probiotic, Prebiotic, and Synbiotic Supplementation in the Neonate}

Interest in the provision of probiotics, prebiotics, or synbiotics directly to neonates that are at risk of dysbiosis of the gut microbiome has exploded in recent years (255). Preterm infants are at particular risk of dysbiosis, not only due to gut immaturity, but because they often have reduced or delayed enteral feeds and increased exposure to antibiotics. Failure to establish normal gut flora is linked to higher risk of NEC and nosocomial sepsis (288). Systematic review of studies providing probiotics to low-birth weight infants in neonatal units, suggest a reduction in grade II or
III NEC and all-cause mortality, though no significant reductions in sepsis $(289,290)$. Not all studies have shown clear benefits for NEC, however, and multistrain probiotics appear more beneficial than single strain organisms (291). Prebiotic supplements have not been shown to result in significant reduction in NEC, allcause mortality or sepsis when given to preterm infants (292). The long-term health implications of use of pre- and probiotic supplements in preterm infants are not currently known. Provision of probiotics and prebiotics to formula fed infants, in attempts to produce a gut microbiome profile similar to breastfed infants, has also been extensively studied. Although beyond the scope of this review, these studies suggest reductions in atopic disease (though few studies have follow-up of sufficient duration to assess long-term effects) (293) and some limited evidence on systematic review for reductions in gastrointestinal and respiratory infections $(294,295)$. More excitingly, a recent randomized controlled trial in breastfed infants in rural India showed that synbiotic administration during the first 7 days of life led to a $40 \%$ reduction in sepsis and all-cause mortality in the first 60 days of life (296). This suggests that in certain situations even the breastfed microbiome may be altered for immunological benefits in the early neonatal period. However, further studies to examine the effect of different strains, dosages and durations, as well as the long-term consequences of synbiotic administration, will be needed before synbiotics could be considered as a public health intervention for neonatal sepsis.

\section{SUMMARY}

Despite multiple animal and human studies associating nutrient deficiencies with adverse immunological outcomes, there is strikingly little evidence to suggest nutritional supplementation during gestation and early infancy has benefits for neonatal responses to infection or allergic disease prevention.

There are a number of plausible explanations for the lack of significant and consistent impacts of individual or combined nutrient supplements on neonatal outcomes. First, it may reflect the heterogeneity of the studied populations in-terms of their underlying nutritional status. Improvements in clinical outcomes are likely to be most where deficiencies are highest. The transfer of many nutrients across the placenta, such as vitamin A (177) and iron (179), occurs actively and is regulated by the fetus, meaning that even in the context of maternal insufficiency the fetus remains relatively protected. As a result, maternal supplementation might only benefit infants born to mothers with critical deficiencies. Large population studies including non-deficient participants will have reduced power to detect clinical benefit. Maternal vitamin A supplementation, for instance, had larger effects on maternal and neonatal outcomes in Nepal (297), where severe deficiency is common, compared to Ghana (298) and Bangladesh (299) where levels of deficiency are more moderate (177). Second, in many studies iron and folate were provided to mothers in the non-intervention arm. As these can also impact on neonatal infective outcomes, this may have confounded the results (156). Third, the optimal level of supplementation of micro- and macronutrients for neonatal outcomes is not known and dosages often differ between studies (300). Micronutrients 
have nutrient-nutrient interactions that may alter the availability of other immunity modulating nutrients and have a rate-limiting effect on immune development (301). High levels of iron, zinc, and protein, for instance, can have counterintuitively negative effects on the immune system, and may have detrimental outcomes when given to sufficient women (302). If this is the case, then population-based treatment as a public health intervention becomes challenging and less measurably effective. Fourth, it may be that the onset of maternal supplementation in the studies was too late in gestation to have lasting effects on immune system development. Supplementation was commenced after 12 weeks of age in many studies, which would miss an early programming effect of nutrients if one exists. As a number of supplementation studies reported improvements in mothers nutrient status following supplementation, but no improvements in clinical outcome for the offspring, it would be interesting to know whether this enhanced nutritional status had positive impacts on future pregnancies, by improving nutrient status during the periconceptional period. Lastly, despite the large number of studies investigating maternal nutrient supplementation, those designed specifically to look at the effects on neonatal immune development and infectious/allergic disease outcomes are limited and further research with more sensitive outcome markers is warranted.

Although the evidence for the benefits of nutritional supplements in pregnancy and early infancy has so far been disappointing, some exciting possibilities remain. The persisting epigenetic changes induced by nutritional factors around the time of conception, which may impact on immune functioning in later life, warrants further study to assess their impact on neonatal

\section{REFERENCES}

1. Lawn JE, Blencowe H, Oza S, You D, Lee AC, Waiswa P, et al. Every newborn: progress, priorities, and potential beyond survival. Lancet (2014) 384(9938):189-205. doi:10.1016/S0140-6736(14)60496-7

2. Jones KD, Berkley JA, Warner JO. Perinatal nutrition and immunity to infection. Pediatr Allergy Immunol (2010) 21(4 Pt 1):564-76. doi:10.1111/j. 1399-3038.2010.01002.x

3. Newburg DS, Walker WA. Protection of the neonate by the innate immune system of developing gut and of human milk. Pediatr Res (2007) 61(1):2-8. doi:10.1203/01.pdr.0000250274.68571.18

4. Pettengill MA, van Haren SD, Levy O. Soluble mediators regulating immunity in early life. Front Immunol (2014) 5:457. doi:10.3389/fimmu.2014.00457

5. Wynn JL, Neu J, Moldawer LL, Levy O. Potential of immunomodulatory agents for prevention and treatment of neonatal sepsis. J Perinatol (2009) 29(2):79-88. doi:10.1038/jp.2008.132

6. Marzi M, Vigano A, Trabattoni D, Villa ML, Salvaggio A, Clerici E, et al. Characterization of type 1 and type 2 cytokine production profile in physiologic and pathologic human pregnancy. Clin Exp Immunol (1996) 106(1):127-33. doi:10.1046/j.1365-2249.1996.d01-809.x

7. Dowling DJ, Levy O. Ontogeny of early life immunity. Trends Immunol (2014) 35(7):299-310. doi:10.1016/j.it.2014.04.007

8. Lumey LH, Stein AD, Kahn HS, van der Pal-de Bruin KM, Blauw GJ, Zybert PA, et al. Cohort profile: the Dutch Hunger Winter families study. Int J Epidemiol (2007) 36(6):1196-204. doi:10.1093/ije/dym126

9. Barker DJ, Eriksson JG, Forsen T, Osmond C. Fetal origins of adult disease: strength of effects and biological basis. Int J Epidemiol (2002) 31(6):1235-9. doi:10.1093/ije/31.6.1235

10. Painter RC, Roseboom TJ, Bleker OP. Prenatal exposure to the Dutch famine and disease in later life: an overview. Reprod Toxicol (2005) 20(3):345-52. doi:10.1016/j.reprotox.2005.04.005 infections, allergy and the amenability to supplementation. The potential benefit of probiotics and synbiotics for infectious disease and allergic outcomes in infancy is also extremely exciting. The World Allergy Organisation has recently recommended probiotic use during gestation, lactation and early life for infants at high risk of atopic disease (303), but further work to determine the most effective strains, dosage and duration, and whether these vary by geographical region, will be needed before their widespread use as a public health intervention against neonatal infections can be recommended.

\section{AUTHOR CONTRIBUTIONS}

SP was responsible for all parts of this article.

\section{ACKNOWLEDGMENTS}

The author would like to thank Professor Andrew Prentice for comments on the first draft of this manuscript, Dr. Stephen Cose for discussions surrounding potential immunological mechanisms, and Professor Beate Kampmann, Dr. Kirsty Le Doare, Dr. Elizabeth Whittaker, and Dr. Christine Jones for inviting me to present this work at the Royal Society of Medicine Neonatal Infection and Immunity symposium.

\section{FUNDING}

SP is funded by a Wellcome Trust Clinical Fellowship (grant number 102915/Z/13/Z).
11. Kereliuk SM, Brawerman GM, Dolinsky VW. Maternal macronutrient consumption and the developmental origins of metabolic disease in the offspring. Int J Mol Sci (2017) 18(7):1451. doi:10.3390/ijms18071451

12. Zimmermann MB. Iodine deficiency in pregnancy and the effects of maternal iodine supplementation on the offspring: a review. Am J Clin Nutr (2009) 89(2):668S-72S. doi:10.3945/ajcn.2008.26811C

13. De-Regil LM, Fernandez-Gaxiola AC, Dowswell T, Pena-Rosas JP. Effects and safety of periconceptional folate supplementation for preventing birth defects. Cochrane Database Syst Rev (2010) 10:CD007950. doi:10.1002/14651858. CD007950.pub2

14. Moore SE, Cole TJ, Collinson AC, Poskitt EM, McGregor IA, Prentice AM. Prenatal or early postnatal events predict infectious deaths in young adulthood in rural Africa. Int J Epidemiol (1999) 28(6):1088-95. doi:10.1093/ije/28.6.1088

15. Moore SE. Early-life nutritional programming of health and disease in the Gambia. Ann Nutr Metab (2017) 70(3):179-83. doi:10.1159/000456555

16. Ibrahim MK, Zambruni M, Melby CL, Melby PC. Impact of childhood malnutrition on host defense and infection. Clin Microbiol Rev (2017) 30(4):919-71. doi:10.1128/CMR.00119-16

17. Cunningham-Rundles S, McNeeley DF, Moon A. Mechanisms of nutrient modulation of the immune response. JAllergy Clin Immunol (2005) 115(6):1119-28; quiz 1129. doi:10.1016/j.jaci.2005.04.036

18. Calder PC. Omega-3 fatty acids and inflammatory processes. Nutrients (2010) 2(3):355-74. doi:10.3390/nu2030355

19. Calder PC. Omega-3 polyunsaturated fatty acids and inflammatory processes: nutrition or pharmacology? Br JClin Pharmacol (2013) 75(3):645-62. doi:10.1111/j.1365-2125.2012.04374.x

20. Endres S, Ghorbani R, Kelley VE, Georgilis K, Lonnemann G, van der Meer JW, et al. The effect of dietary supplementation with n-3 polyunsaturated fatty acids on the synthesis of interleukin-1 and tumor necrosis factor by mononuclear cells. N Engl J Med (1989) 320(5):265-71. doi:10.1056/ NEJM198902023200501 
21. Calder PC. Dietary fatty acids and lymphocyte functions. Proc Nutr Soc (1998) 57(4):487-502. doi:10.1079/PNS19980073

22. Fritsche K. Fatty acids as modulators of the immune response. Annu Rev Nutr (2006) 26:45-73. doi:10.1146/annurev.nutr.25.050304.092610

23. Fetterman JW Jr, Zdanowicz MM. Therapeutic potential of n-3 polyunsaturated fatty acids in disease. Am J Health Syst Pharm (2009) 66(13):1169-79. doi:10.2146/ajhp080411

24. Damsgaard CT, Lauritzen L, Kjaer TM, Holm PM, Fruekilde MB, Michaelsen KF, et al. Fish oil supplementation modulates immune function in healthy infants. J Nutr (2007) 137(4):1031-6.

25. Manzanares W, Langlois PL, Dhaliwal R, Lemieux M, Heyland DK. Intravenous fish oil lipid emulsions in critically ill patients: an updated systematic review and meta-analysis. Crit Care (2015) 19:167. doi:10.1186/ s13054-015-0888-7

26. Pino-Lagos K, Guo Y, Noelle RJ. Retinoic acid: a key player in immunity. Biofactors (2010) 36(6):430-6. doi:10.1002/biof.117

27. Stephensen CB. Vitamin A, infection, and immune function. Annu Rev Nutr (2001) 21:167-92. doi:10.1146/annurev.nutr.21.1.167

28. Imdad A, Mayo-Wilson E, Herzer K, Bhutta ZA. Vitamin A supplementation for preventing morbidity and mortality in children from six months to five years of age. Cochrane Database Syst Rev (2017) 3:CD008524. doi:10.1002/14651858.CD008524.pub3

29. Chandra RK, Sudhakaran L. Regulation of immune responses by vitamin B6. Ann N Y Acad Sci (1990) 585:404-23. doi:10.1111/j.1749-6632.1990.tb28073.x

30. Rall LC, Meydani SN. Vitamin B6 and immune competence. Nutr Rev (1993) 51(8):217-25. doi:10.1111/j.1753-4887.1993.tb03109.x

31. Trakatellis A, Dimitriadou A, Trakatelli M. Pyridoxine deficiency: new approaches in immunosuppression and chemotherapy. Postgrad Med J (1997) 73(864):617-22. doi:10.1136/pgmj.73.864.617

32. Wintergerst ES, Maggini S, Hornig DH. Contribution of selected vitamins and trace elements to immune function. Ann Nutr Metab (2007) 51(4):301-23. doi:10.1159/000107673

33. Tamura J, Kubota K, Murakami H, Sawamura M, Matsushima T, Tamura T, et al. Immunomodulation by vitamin B12: augmentation of CD8+ T lymphocytes and natural killer (NK) cell activity in vitamin B12-deficient patients by methyl-B12 treatment. Clin Exp Immunol (1999) 116(1):28-32. doi:10.1046/j. 1365-2249.1999.00870.x

34. Abe SK, Balogun OO, Ota E, Takahashi K, Mori R. Supplementation with multiple micronutrients for breastfeeding women for improving outcomes for the mother and baby. Cochrane Database Syst Rev (2016) 2:CD010647. doi:10.1002/14651858.CD010647.pub2

35. Schramm M, Wiegmann K, Schramm S, Gluschko A, Herb M, Utermohlen O, et al. Riboflavin (vitamin B2) deficiency impairs NADPH oxidase 2 (Nox2) priming and defense against Listeria monocytogenes. Eur J Immunol (2014) 44(3):728-41. doi:10.1002/eji.201343940

36. Kuroishi T. Regulation of immunological and inflammatory functions by biotin. Can J Physiol Pharmacol (2015) 93(12):1091-6. doi:10.1139/cjpp2014-0460

37. Maggini S, Wintergerst ES, Beveridge S, Hornig DH. Selected vitamins and trace elements support immune function by strengthening epithelial barriers and cellular and humoral immune responses. Br J Nutr (2007) 98(Suppl 1): S29-35. doi:10.1017/S0007114507832971

38. Agrawal S, Agrawal A, Said HM. Biotin deficiency enhances the inflammatory response of human dendritic cells. Am J Physiol Cell Physiol (2016) 311(3):C386-91. doi:10.1152/ajpcell.00141.2016

39. Fata FT, Herzlich BC, Schiffman G, Ast AL. Impaired antibody responses to pneumococcal polysaccharide in elderly patients with low serum vitamin B12 levels. Ann Intern Med (1996) 124(3):299-304. doi:10.7326/0003-4819124-3-199602010-00003

40. Hemila H. Vitamin C and infections. Nutrients (2017) 9(4):339. doi:10.3390/ nu9040339

41. Wei R, Christakos S. Mechanisms underlying the regulation of innate and adaptive immunity by vitamin D. Nutrients (2015) 7(10):8251-60. doi:10.3390/ nu7105392

42. Yakoob MY, Salam RA, Khan FR, Bhutta ZA. Vitamin D supplementation for preventing infections in children under five years of age. Cochrane Database Syst Rev (2016) 11:CD008824. doi:10.1002/14651858.CD008824.pub2

43. Martineau AR, Jolliffe DA, Hooper RL, Greenberg L, Aloia JF, Bergman P, et al. Vitamin D supplementation to prevent acute respiratory tract infections: systematic review and meta-analysis of individual participant data. $B M J$ (2017) 356:i6583. doi:10.1136/bmj.i6583

44. Meydani SN, Leka LS, Fine BC, Dallal GE, Keusch GT, Singh MF, et al. Vitamin $\mathrm{E}$ and respiratory tract infections in elderly nursing home residents: a randomized controlled trial. JAMA (2004) 292(7):828-36. doi:10.1001/ jama.292.7.828

45. Meydani SN, Han SN, Wu D. Vitamin E and immune response in the aged: molecular mechanisms and clinical implications. Immunol Rev (2005) 205:269-84. doi:10.1111/j.0105-2896.2005.00274.x

46. Wellinghausen N. Immunobiology of gestational zinc deficiency. Br J Nutr (2001) 85(Suppl 2):S81-6. doi:10.1079/BJN2000298

47. Lassi ZS, Moin A, Bhutta ZA. Zinc supplementation for the prevention of pneumonia in children aged 2 months to 59 months. Cochrane Database Syst Rev (2016) 12:CD005978. doi:10.1002/14651858.CD005978.pub3

48. Lazzerini M, Wanzira H. Oral zinc for treating diarrhoea in children. Cochrane Database Syst Rev (2016) 12:CD005436. doi:10.1002/14651858.CD005436. pub5

49. Prasad AS. Clinical, immunological, anti-inflammatory and antioxidant roles of zinc. Exp Gerontol (2008) 43(5):370-7. doi:10.1016/j.exger.2007.10.013

50. Prasad AS. Zinc: role in immunity, oxidative stress and chronic inflammation. Curr Opin Clin Nutr Metab Care (2009) 12(6):646-52. doi:10.1097/MCO. 0b013e3283312956

51. Arthur JR, McKenzie RC, Beckett GJ. Selenium in the immune system. J Nutr (2003) 133(5 Suppl 1):1457S-9S.

52. Li W, Beck MA. Selenium deficiency induced an altered immune response and increased survival following influenza A/Puerto Rico/8/34 infection. Exp Biol Med (Maywood) (2007) 232(3):412-9.

53. Broome CS, McArdle F, Kyle JA, Andrews F, Lowe NM, Hart CA, et al. An increase in selenium intake improves immune function and poliovirus handling in adults with marginal selenium status. Am J Clin Nutr (2004) 80(1): $154-62$.

54. Huang Z, Rose AH, Hoffmann PR. The role of selenium in inflammation and immunity: from molecular mechanisms to therapeutic opportunities. Antioxid Redox Signal (2012) 16(7):705-43. doi:10.1089/ars.2011.4145

55. Drakesmith H, Prentice AM. Hepcidin and the iron-infection axis. Science (2012) 338(6108):768-72. doi:10.1126/science.1224577

56. Oppenheimer SJ. Iron and its relation to immunity and infectious disease. J Nutr (2001) 131(2S-2):616S-33S.

57. Malek A, Sager R, Kuhn P, Nicolaides KH, Schneider H. Evolution of maternofetal transport of immunoglobulins during human pregnancy. Am J Reprod Immunol (1996) 36(5):248-55. doi:10.1111/j.1600-0897.1996.tb00172.x

58. Wu GI-H, Girard AW. Biological mechanisms for nutritional regulation of maternal health and fetal development. Paediatr Perinat Epidemiol (2012) 26(Suppl 1):4-26. doi:10.1111/j.1365-3016.2012.01291.x

59. Cetin I, Berti C, Calabrese S. Role of micronutrients in the periconceptional period. Hum Reprod Update (2010) 16(1):80-95. doi:10.1093/humupd/dmp025

60. Hindmarsh PC, Geary MP, Rodeck CH, Jackson MR, Kingdom JC. Effect of early maternal iron stores on placental weight and structure. Lancet (2000) 356(9231):719-23. doi:10.1016/S0140-6736(00)02630-1

61. Borowicz PP, Arnold DR, Johnson ML, Grazul-Bilska AT, Redmer DA, Reynolds LP. Placental growth throughout the last two thirds of pregnancy in sheep: vascular development and angiogenic factor expression. Biol Reprod (2007) 76(2):259-67. doi:10.1095/biolreprod.106.054684

62. Reynolds LP, Borowicz PP, Caton JS, Vonnahme KA, Luther JS, Buchanan DS, et al. Uteroplacental vascular development and placental function: an update. Int J Dev Biol (2010) 54(2-3):355-66. doi:10.1387/ijdb.082799lr

63. Fowden AL, Ward JW, Wooding FP, Forhead AJ, Constancia M. Programming placental nutrient transport capacity. J Physiol (2006) 572(Pt 1):5-15. doi:10.1113/ jphysiol.2005.104141

64. Soliman AT, ElZalabany MM, Salama M, Ansari BM. Serum leptin concentrations during severe protein-energy malnutrition: correlation with growth parameters and endocrine function. Metabolism (2000) 49(7):819-25. doi:10.1053/meta.2000.6745

65. DePasquale-Jardieu P, Fraker PJ. The role of corticosterone in the loss in immune function in the zinc-deficient A/J mouse. J Nutr (1979) 109(11): 1847-55.

66. DePasquale-Jardieu P, Fraker PJ. Further characterization of the role of corticosterone in the loss of humoral immunity in zinc-deficient $\mathrm{A} / \mathrm{J}$ mice as determined by adrenalectomy. J Immunol (1980) 124(6):2650-5. 
67. Martin R, Nauta AJ, Ben Amor K, Knippels LM, Knol J, Garssen J. Early life: gut microbiota and immune development in infancy. Benef Microbes (2010) 1(4):367-82. doi:10.3920/BM2010.0027

68. Hooper LV, Littman DR, Macpherson AJ. Interactions between the microbiota and the immune system. Science (2012) 336(6086):1268-73. doi:10.1126/ science. 1223490

69. Backhed F, Ding H, Wang T, Hooper LV, Koh GY, Nagy A, et al. The gut microbiota as an environmental factor that regulates fat storage. Proc Natl Acad Sci US A (2004) 101(44):15718-23. doi:10.1073/pnas.0407076101

70. Holmes E, Li JV, Marchesi JR, Nicholson JK. Gut microbiota composition and activity in relation to host metabolic phenotype and disease risk. Cell Metab (2012) 16(5):559-64. doi:10.1016/j.cmet.2012.10.007

71. Clark A, Mach N. Role of vitamin D in the hygiene hypothesis: the interplay between vitamin $\mathrm{D}$, vitamin $\mathrm{D}$ receptors, gut microbiota, and immune response. Front Immunol (2016) 7:627. doi:10.3389/fimmu.2016.00627

72. Sanz Y. Gut microbiota and probiotics in maternal and infant health. Am J Clin Nutr (2011) 94(6 Suppl):2000S-5S. doi:10.3945/ajen.110.001172

73. Petersen C, Round JL. Defining dysbiosis and its influence on host immunity and disease. Cell Microbiol (2014) 16(7):1024-33. doi:10.1111/cmi.12308

74. Macpherson AJ, de Aguero MG, Ganal-Vonarburg SC. How nutrition and the maternal microbiota shape the neonatal immune system. Nat Rev Immunol (2017) 17(8):508-17. doi:10.1038/nri.2017.58

75. Zinkernagel RM. Maternal antibodies, childhood infections, and autoimmune diseases. N Engl J Med (2001) 345(18):1331-5. doi:10.1056/NEJMra012493

76. Koch MA, Reiner GL, Lugo KA, Kreuk LS, Stanbery AG, Ansaldo E, et al. Maternal IgG and IgA antibodies dampen mucosal T helper cell responses in early life. Cell (2016) 165(4):827-41. doi:10.1016/j.cell.2016.04.055

77. Gomez de Aguero M, Ganal-Vonarburg SC, Fuhrer T, Rupp S, Uchimura Y, $\mathrm{Li} \mathrm{H}$, et al. The maternal microbiota drives early postnatal innate immune development. Science (2016) 351(6279):1296-302. doi:10.1126/science. aad 2571

78. Aagaard K, Ma J, Antony KM, Ganu R, Petrosino J, Versalovic J. The placenta harbors a unique microbiome. Sci Transl Med (2014) 6(237):237ra65. doi:10.1126/scitranslmed.3008599

79. Burdge GC, Lillycrop KA. Nutrition, epigenetics, and developmental plasticity: implications for understanding human disease. Annu Rev Nutr (2010) 30:315-39. doi:10.1146/annurev.nutr.012809.104751

80. Jaenisch R, Bird A. Epigenetic regulation of gene expression: how the genome integrates intrinsic and environmental signals. Nat Genet (2003) 33(Suppl):245-54. doi:10.1038/ng1089

81. Canani RB, Costanzo MD, Leone L, Bedogni G, Brambilla P, Cianfarani S, et al. Epigenetic mechanisms elicited by nutrition in early life. Nutr Res Rev (2011) 24(2):198-205. doi:10.1017/S0954422411000102

82. Lillycrop KA, Burdge GC. Maternal diet as a modifier of offspring epigenetics. J Dev Orig Health Dis (2015) 6(2):88-95. doi:10.1017/S2040174415000124

83. Heijmans BT, Tobi EW, Stein AD, Putter H, Blauw GJ, Susser ES, et al. Persistent epigenetic differences associated with prenatal exposure to famine in humans. Proc Natl Acad Sci U S A (2008) 105(44):17046-9. doi:10.1073/ pnas. 0806560105

84. Tobi EW, Lumey LH, Talens RP, Kremer D, Putter H, Stein AD, et al. DNA methylation differences after exposure to prenatal famine are common and timing- and sex-specific. Hum Mol Genet (2009) 18(21):4046-53. doi:10.1093/ hmg/ddp353

85. Rytter MJ, Namusoke H, Ritz C, Michaelsen KF, Briend A, Friis H, et al. Correlates of thymus size and changes during treatment of children with severe acute malnutrition: a cohort study. BMC Pediatr (2017) 17(1):70. doi:10.1186/s12887-017-0821-0

86. Leonhardt M, Lesage J, Dufourny L, Dickes-Coopman A, Montel V, Dupouy JP. Perinatal maternal food restriction induces alterations in hypothalamopituitary-adrenal axis activity and in plasma corticosterone-binding globulin capacity of weaning rat pups. Neuroendocrinology (2002) 75(1):45-54. doi:10.1159/000048220

87. Rothenbacher H, Sherman AR. Target organ pathology in iron-deficient suckling rats. J Nutr (1980) 110(8):1648-54.

88. Langley-Evans SC, Phillips GJ, Jackson AA. Fetal exposure to low protein maternal diet alters the susceptibility of young adult rats to sulfur dioxideinduced lung injury. J Nutr (1997) 127(2):202-9.

89. Beach RS, Gershwin ME, Hurley LS. Reversibility of development retardation following murine fetal zinc deprivation. J Nutr (1982) 112(6):1169-81.
90. Matthews SG. Early programming of the hypothalamo-pituitary-adrenal axis. Trends Endocrinol Metab (2002) 13(9):373-80. doi:10.1016/S1043-2760 (02)00690-2

91. Shanks N, Lightman SL. The maternal-neonatal neuro-immune interface: are there long-term implications for inflammatory or stress-related disease? J Clin Invest (2001) 108(11):1567-73. doi:10.1172/JCI200114592

92. Jansson T, Powell TL. Role of the placenta in fetal programming: underlying mechanisms and potential interventional approaches. Clin Sci (Lond) (2007) 113(1):1-13. doi:10.1042/CS20060339

93. Palmer AC. Nutritionally mediated programming of the developing immune system. Adv Nutr (2011) 2(5):377-95. doi:10.3945/an.111.000570

94. Firmansyah A, Chongviriyaphan N, Dillon DH, Khan NC, Morita T, Tontisirin $\mathrm{K}$, et al. Fructans in the first 1000 days of life and beyond, and for pregnancy. Asia Pac J Clin Nutr (2016) 25(4):652-75. doi:10.6133/apjcn. 092016.02

95. Dominguez-Salas P, Moore SE, Cole D, da Costa KA, Cox SE, Dyer RA, et al. DNA methylation potential: dietary intake and blood concentrations of one-carbon metabolites and cofactors in rural African women. Am J Clin Nutr (2013) 97(6):1217-27. doi:10.3945/ajcn.112.048462

96. Dominguez-Salas P, Moore SE, Baker MS, Bergen AW, Cox SE, Dyer RA, et al. Maternal nutrition at conception modulates DNA methylation of human metastable epialleles. Nat Commun (2014) 5:3746. doi:10.1038/ ncomms 4746

97. Dominguez-Salas P, Cox SE, Prentice AM, Hennig BJ, Moore SE. Maternal nutritional status, $C(1)$ metabolism and offspring DNA methylation: a review of current evidence in human subjects. Proc Nutr Soc (2012) 71(1):154-65. doi:10.1017/S0029665111003338

98. Bates CJ, Fuller NJ, Prentice AM. Folate status during pregnancy and lactation in a West African rural community. Hum Nutr Clin Nutr (1986) 40(1):3-13.

99. Waterland RA, Kellermayer R, Laritsky E, Rayco-Solon P, Harris RA, Travisano M, et al. Season of conception in rural gambia affects DNA methylation at putative human metastable epialleles. PLoS Genet (2010) 6(12):e1001252. doi:10.1371/journal.pgen.1001252

100. Silver MJ, Kessler NJ, Hennig BJ, Dominguez-Salas P, Laritsky E, Baker MS, et al. Independent genomewide screens identify the tumor suppressor VTRNA2-1 as a human epiallele responsive to periconceptional environment. Genome Biol (2015) 16:118. doi:10.1186/s13059-015-0660-y

101. Rakyan VK, Blewitt ME, Druker R, Preis JI, Whitelaw E. Metastable epialleles in mammals. Trends Genet (2002) 18(7):348-51. doi:10.1016/ S0168-9525(02)02709-9

102. Morgan HD, Sutherland HG, Martin DI, Whitelaw E. Epigenetic inheritance at the agouti locus in the mouse. Nat Genet (1999) 23(3):314-8. doi:10.1038/ 15490

103. Vasicek TJ, Zeng L, Guan XJ, Zhang T, Costantini F, Tilghman SM. Two dominant mutations in the mouse fused gene are the result of transposon insertions. Genetics (1997) 147(2):777-86.

104. Wolff GL, Roberts DW, Mountjoy KG. Physiological consequences of ectopic agouti gene expression: the yellow obese mouse syndrome. Physiol Genomics (1999) 1(3):151-63.

105. Dolinoy DC, Huang D, Jirtle RL. Maternal nutrient supplementation counteracts bisphenol A-induced DNA hypomethylation in early development. Proc Natl Acad Sci U S A (2007) 104(32):13056-61. doi:10.1073/pnas.0703739104

106. Waterland RA, Jirtle RL. Transposable elements: targets for early nutritional effects on epigenetic gene regulation. Mol Cell Biol (2003) 23(15):5293-300. doi:10.1128/MCB.23.15.5293-5300.2003

107. McDade TW, Ryan C, Jones MJ, MacIsaac JL, Morin AM, Meyer JM, et al. Social and physical environments early in development predict DNA methylation of inflammatory genes in young adulthood. Proc Natl Acad Sci U S A (2017) 114(29):7611-6. doi:10.1073/pnas.1620661114

108. Nile CJ, Read RC, Akil M, Duff GW, Wilson AG. Methylation status of a single CpG site in the IL6 promoter is related to IL6 messenger RNA levels and rheumatoid arthritis. Arthritis Rheum (2008) 58(9):2686-93. doi:10.1002/ art.23758

109. Needham BL, Smith JA, Zhao W, Wang X, Mukherjee B, Kardia SL, et al. Life course socioeconomic status and DNA methylation in genes related to stress reactivity and inflammation: the multi-ethnic study of atherosclerosis. Epigenetics (2015) 10(10):958-69. doi:10.1080/15592294.2015.1085139

110. Carone BR, Fauquier L, Habib N, Shea JM, Hart CE, Li R, et al. Paternally induced transgenerational environmental reprogramming of metabolic 
gene expression in mammals. Cell (2010) 143(7):1084-96. doi:10.1016/j. cell.2010.12.008

111. Ng SF, Lin RC, Laybutt DR, Barres R, Owens JA, Morris MJ. Chronic high-fat diet in fathers programs beta-cell dysfunction in female rat offspring. Nature (2010) 467(7318):963-6. doi:10.1038/nature09491

112. Ost A, Lempradl A, Casas E, Weigert M, Tiko T, Deniz M, et al. Paternal diet defines offspring chromatin state and intergenerational obesity. Cell (2014) 159(6):1352-64. doi:10.1016/j.cell.2014.11.005

113. Chen Q, Yan M, Cao Z, Li X, Zhang Y, Shi J, et al. Sperm tsRNAs contribute to intergenerational inheritance of an acquired metabolic disorder. Science (2016) 351(6271):397-400. doi:10.1126/science.aad7977

114. Kaati G, Bygren LO, Edvinsson S. Cardiovascular and diabetes mortality determined by nutrition during parents' and grandparents' slow growth period. Eur J Hum Genet (2002) 10(11):682-8. doi:10.1038/sj.ejhg.5200859

115. Pembrey ME, Bygren LO, Kaati G, Edvinsson S, Northstone K, Sjostrom M, et al. Sex-specific, male-line transgenerational responses in humans. Eur J Hum Genet (2006) 14(2):159-66. doi:10.1038/sj.ejhg.5201538

116. Sandovici I, Smith NH, Nitert MD, Ackers-Johnson M, Uribe-Lewis S, Ito Y, et al. Maternal diet and aging alter the epigenetic control of a promoter-enhancer interaction at the Hnf4a gene in rat pancreatic islets. Proc Natl Acad Sci U S A (2011) 108(13):5449-54. doi:10.1073/pnas.1019007108

117. Lie S, Morrison JL, Williams-Wyss O, Ozanne SE, Zhang S, Walker SK, et al. Impact of embryo number and periconceptional undernutrition on factors regulating adipogenesis, lipogenesis, and metabolism in adipose tissue in the sheep fetus. Am J Physiol Endocrinol Metab (2013) 305(8):E931-41. doi:10.1152/ajpendo.00180.2013

118. Lie S, Morrison JL, Williams-Wyss O, Suter CM, Humphreys DT, Ozanne SE, et al. Periconceptional undernutrition programs changes in insulin-signaling molecules and microRNAs in skeletal muscle in singleton and twin fetal sheep. Biol Reprod (2014) 90(1):5. doi:10.1095/biolreprod.113.109751

119. Owens S, Gulati R, Fulford AJ, Sosseh F, Denison FC, Brabin BJ, et al. Periconceptional multiple-micronutrient supplementation and placental function in rural Gambian women: a double-blind, randomized, placebo-controlled trial. Am J Clin Nutr (2015) 102(6):1450-9. doi:10.3945/ ajcn.113.072413

120. Prada JA, Tsang RC. Biological mechanisms of environmentally induced causes of IUGR. Eur J Clin Nutr (1998) 52(Suppl 1):S21-7.

121. Cuttini M, Cortinovis I, Bossi A, de Vonderweid U. Proportionality of small for gestational age babies as a predictor of neonatal mortality and morbidity. Paediatr Perinat Epidemiol (1991) 5(1):56-63. doi:10.1111/j.1365-3016.1992. tb00322.x

122. Ashworth A. Effects of intrauterine growth retardation on mortality and morbidity in infants and young children. Eur J Clin Nutr (1998) 52(Suppl 1): S34-41.

123. Vik T, Vatten L, Markestad T, Ahlsten G, Jacobsen G, Bakketeig LS. Morbidity during the first year of life in small for gestational age infants. Arch Dis Child Fetal Neonatal Ed (1996) 75(1):F33-7. doi:10.1136/fn.75.1.F33

124. Garcia-Basteiro AL, Quinto L, Macete E, Bardaji A, Gonzalez R, Nhacolo A, et al. Infant mortality and morbidity associated with preterm and small-for-gestational-age births in Southern Mozambique: a retrospective cohort study. PLoS One (2017) 12(2):e0172533. doi:10.1371/journal. pone. 0172533

125. Chatrath R, Saili A, Jain M, Dutta AK. Immune status of full-term small-for-gestational age neonates in India. J Trop Pediatr (1997) 43(6):345-8. doi:10.1093/tropej/43.6.345

126. Rathore DK, Nair D, Raza S, Saini S, Singh R, Kumar A, et al. Underweight full-term Indian neonates show differences in umbilical cord blood leukocyte phenotype: a cross-sectional study. PLoS One (2015) 10(4):e0123589. doi:10.1371/journal.pone.0123589

127. Raqib R, Alam DS, Sarker P, Ahmad SM, Ara G, Yunus M, et al. Low birth weight is associated with altered immune function in rural Bangladeshi children: a birth cohort study. Am J Clin Nutr (2007) 85(3):845-52.

128. Collinson AC, Moore SE, Cole TJ, Prentice AM. Birth season and environmental influences on patterns of thymic growth in rural Gambian infants. Acta Paediatr (2003) 92(9):1014-20. doi:10.1111/j.1651-2227.2003.tb02568.x

129. Collinson AC, Ngom PT, Moore SE, Morgan G, Prentice AM. Birth season and environmental influences on blood leucocyte and lymphocyte subpopulations in rural Gambian infants. BMC Immunol (2008) 9:18. doi:10.1186/1471-2172-9-18
130. Moore SE, Collinson AC, Prentice AM. Immune function in rural Gambian children is not related to season of birth, birth size, or maternal supplementation status. Am J Clin Nutr (2001) 74(6):840-7.

131. Ghattas H, Wallace DL, Solon JA, Henson SM, Zhang Y, Ngom PT, et al. Long-term effects of perinatal nutrition on $\mathrm{T}$ lymphocyte kinetics in young Gambian men. Am J Clin Nutr (2007) 85(2):480-7.

132. McDade TW, Beck MA, Kuzawa C, Adair LS. Prenatal undernutrition, postnatal environments, and antibody response to vaccination in adolescence. Am J Clin Nutr (2001) 74(4):543-8.

133. Moore SE, Jalil F, Ashraf R, Szu SC, Prentice AM, Hanson LA. Birth weight predicts response to vaccination in adults born in an urban slum in Lahore, Pakistan. Am J Clin Nutr (2004) 80(2):453-9.

134. Moore SE, Jalil F, Szu SC, Hahn-Zoric M, Prentice AM, Hanson LA. Revaccination does not improve an observed deficit in antibody responses in Pakistani adults born of a lower birth weight. Vaccine (2008) 26(2):158-65. doi:10.1016/j.vaccine.2007.11.007

135. Moore SE, Richards AA, Goldblatt D, Ashton L, Szu SC, Prentice AM. Early-life and contemporaneous nutritional and environmental predictors of antibody response to vaccination in young Gambian adults. Vaccine (2012) 30(32):4842-8. doi:10.1016/j.vaccine.2012.05.009

136. Imdad A, Bhutta ZA. Effect of balanced protein energy supplementation during pregnancy on birth outcomes. BMC Public Health (2011) 11(Suppl 3): S17. doi:10.1186/1471-2458-11-S3-S17

137. Liberato SC, Singh G, Mulholland K. Effects of protein energy supplementation during pregnancy on fetal growth: a review of the literature focusing on contextual factors. Food Nutr Res (2013) 57:20499. doi:10.3402/fnr.v57i0.20499

138. Rush D, Stein Z, Susser M. A randomized controlled trial of prenatal nutritional supplementation in New York City. Pediatrics (1980) 65(4):683-97.

139. Mora JO, de Paredes B, Wagner M, de Navarro L, Suescun J, Christiansen N, et al. Nutritional supplementation and the outcome of pregnancy. I. Birth weight. Am J Clin Nutr (1979) 32(2):455-62.

140. Ceesay SM, Prentice AM, Cole TJ, Foord F, Weaver LT, Poskitt EM, et al. Effects on birth weight and perinatal mortality of maternal dietary supplements in rural Gambia: 5 year randomised controlled trial. BMJ (1997) 315(7111): 786-90. doi:10.1136/bmj.315.7111.786

141. Moore SE, Prentice AM, Wagatsuma Y, Fulford AJ, Collinson AC, Raqib R, et al. Early-life nutritional and environmental determinants of thymic size in infants born in rural Bangladesh. Acta Paediatr (2009) 98(7):1168-75. doi:10.1111/j.1651-2227.2009.01292.x

142. Kar S, Wong M, Rogozinska E, Thangaratinam S. Effects of omega-3 fatty acids in prevention of early preterm delivery: a systematic review and meta-analysis of randomized studies. Eur J Obstet Gynecol Reprod Biol (2016) 198:40-6. doi:10.1016/j.ejogrb.2015.11.033

143. Gunaratne AW, Makrides M, Collins CT. Maternal prenatal and/or postnatal n-3 long chain polyunsaturated fatty acids (LCPUFA) supplementation for preventing allergies in early childhood. Cochrane Database Syst Rev (2015) 7:CD010085. doi:10.1002/14651858.CD010085.pub2

144. Best KP, Gold M, Kennedy D, Martin J, Makrides M. Omega-3 long-chain PUFA intake during pregnancy and allergic disease outcomes in the offspring: a systematic review and meta-analysis of observational studies and randomized controlled trials. Am JClin Nutr (2016) 103(1):128-43. doi:10.3945/ajcn.115.111104

145. van Vlies N, Hogenkamp A, Fear AL, van Esch BC, Oosting A, van de Heijning B, et al. Perinatal programming of murine immune responses by polyunsaturated fatty acids. J Dev Orig Health Dis (2011) 2(2):112-23. doi:10.1017/ S204017441000067X

146. Granot E, Jakobovich E, Rabinowitz R, Levy P, Schlesinger M. DHA supplementation during pregnancy and lactation affects infants' cellular but not humoral immune response. Mediators Inflamm (2011) 2011:493925. doi: $10.1155 / 2011 / 493925$

147. Imhoff-Kunsch B, Stein AD, Martorell R, Parra-Cabrera S, Romieu I, Ramakrishnan U. Prenatal docosahexaenoic acid supplementation and infant morbidity: randomized controlled trial. Pediatrics (2011) 128(3):e505-12. doi:10.1542/peds.2010-1386

148. Saccone G, Berghella V. Omega-3 long chain polyunsaturated fatty acids to prevent preterm birth: a systematic review and meta-analysis. Obstet Gynecol (2015) 125(3):663-72. doi:10.1097/AOG.0000000000000668

149. Bailey RL, West KP Jr, Black RE. The epidemiology of global micronutrient deficiencies. Ann Nutr Metab (2015) 66(Suppl 2):22-33. doi:10.1159/000371618 
150. Gammoh NZ, Rink L. Zinc in Infection and Inflammation. Nutrients (2017) 9(6). doi:10.3390/nu9060624

151. Caulfield LE, Zavaleta N, Figueroa A. Adding zinc to prenatal iron and folate supplements improves maternal and neonatal zinc status in a Peruvian population. Am J Clin Nutr (1999) 69(6):1257-63.

152. Osendarp SJ, van Raaij JM, Arifeen SE, Wahed M, Baqui AH, Fuchs GJ. A randomized, placebo-controlled trial of the effect of zinc supplementation during pregnancy on pregnancy outcome in Bangladeshi urban poor. Am J Clin Nutr (2000) 71(1):114-9.

153. Kumar A, Pandey M, Basu S, Shukla RC, Asthana RK. Thymic size correlates with cord blood zinc levels in low-birth-weight newborns. Eur J Pediatr (2014) 173(8):1083-7. doi:10.1007/s00431-014-2293-7

154. Ahmad SM, Hossain MB, Monirujjaman M, Islam S, Huda MN, Kabir Y, et al. Maternal zinc supplementation improves hepatitis B antibody responses in infants but decreases plasma zinc level. Eur J Nutr (2016) 55(5):1823-9. doi:10.1007/s00394-015-0999-6

155. Osendarp SJ, Fuchs GJ, van Raaij JM, Mahmud H, Tofail F, Black RE, et al. The effect of zinc supplementation during pregnancy on immune response to Hib and BCG vaccines in Bangladesh. J Trop Pediatr (2006) 52(5):316-23. doi:10.1093/tropej/fml012

156. Ota E, Mori R, Middleton P, Tobe-Gai R, Mahomed K, Miyazaki C, et al. Zinc supplementation for improving pregnancy and infant outcome. Cochrane Database Syst Rev (2015) 2:CD000230.

157. Osendarp SJ, van Raaij JM, Darmstadt GL, Baqui AH, Hautvast JG, Fuchs GJ. Zinc supplementation during pregnancy and effects on growth and morbidity in low birthweight infants: a randomised placebo controlled trial. Lancet (2001) 357(9262):1080-5. doi:10.1016/S0140-6736(00)04260-4

158. Darmstadt GL, Osendarp SJ, Ahmed S, Feldman C, Van Raaij JM, Baqui AH, et al. Effect of antenatal zinc supplementation on impetigo in infants in Bangladesh. Pediatr Infect Dis J (2012) 31(4):407-9. doi:10.1097/INF. 0b013e318243e232

159. Wieringa FT, Dijkhuizen MA, Muhilal, Van der Meer JW. Maternal micronutrient supplementation with zinc and beta-carotene affects morbidity and immune function of infants during the first 6 months of life. Eur J Clin Nutr (2010) 64(10):1072-9. doi:10.1038/ejcn.2010.115

160. Iannotti LL, Zavaleta N, Leon Z, Shankar AH, Caulfield LE. Maternal zinc supplementation and growth in Peruvian infants. Am J Clin Nutr (2008) 88(1):154-60.

161. Wegienka G, Kaur H, Sangha R, Cassidy-Bushrow AE. Maternal-cord blood vitamin D correlations vary by maternal levels. J Pregnancy (2016) 2016:7474192. doi:10.1155/2016/7474192

162. Perez-Lopez FR, Pasupuleti V, Mezones-Holguin E, Benites-Zapata VA, Thota P, Deshpande A, et al. Effect of vitamin D supplementation during pregnancy on maternal and neonatal outcomes: a systematic review and meta-analysis of randomized controlled trials. Fertil Steril (2015) 103(5):1278-88.e4. doi:10.1016/j.fertnstert.2015.02.019

163. Yang N, Wang L, Li Z, Chen S, Li N, Ye R. Effects of vitamin D supplementation during pregnancy on neonatal vitamin $\mathrm{D}$ and calcium concentrations: a systematic review and meta-analysis. Nutr Res (2015) 35(7):547-56. doi:10.1016/j. nutres.2015.04.010

164. Gur EB, Gur MS, Ince O, Kasap E, Genc M, Tatar S, et al. Vitamin D deficiency in pregnancy may affect fetal thymus development. Ginekol Pol (2016) 87(5):378-83. doi:10.5603/GP.2016.0008

165. Rosendahl J, Holmlund-Suila E, Helve O, Viljakainen H, Hauta-Alus H, Valkama S, et al. 25-hydroxyvitamin D correlates with inflammatory markers in cord blood of healthy newborns. Pediatr Res (2017) 81(5):731-5. doi:10.1038/ pr.2017.9

166. Tao RX, Zhou QF, Xu ZW, Hao JH, Huang K, Mou Z, et al. Inverse correlation between vitamin D and C-reactive protein in newborns. Nutrients (2015) 7(11):9218-28. doi:10.3390/nu7115468

167. Akhtar E, Mily A, Haq A, Al-Mahmud A, El-Arifeen S, Hel Baqui A, et al. Prenatal high-dose vitamin D3 supplementation has balanced effects on cord blood Th1 and Th2 responses. Nutr J (2016) 15(1):75. doi:10.1186/ s12937-016-0194-5

168. Christensen N, Sondergaard J, Fisker N, Christesen HT. Infant respiratory tract infections or wheeze and maternal vitamin $\mathrm{d}$ in pregnancy: a systematic review. Pediatr Infect Dis J (2017) 36(4):384-91. doi:10.1097/INF. 0000000000001452
169. Belderbos ME, Houben ML, Wilbrink B, Lentjes E, Bloemen EM, Kimpen JL, et al. Cord blood vitamin D deficiency is associated with respiratory syncytial virus bronchiolitis. Pediatrics (2011) 127(6):e1513-20. doi:10.1542/ peds.2010-3054

170. Grant CC, Kaur S, Waymouth E, Mitchell EA, Scragg R, Ekeroma A, et al. Reduced primary care respiratory infection visits following pregnancy and infancy vitamin D supplementation: a randomised controlled trial. Acta Paediatr (2015) 104(4):396-404. doi:10.1111/apa.12819

171. Goldring ST, Griffiths CJ, Martineau AR, Robinson S, Yu C, Poulton S, et al. Prenatal vitamin $\mathrm{d}$ supplementation and child respiratory health: a randomised controlled trial. PLoS One (2013) 8(6):e66627. doi:10.1371/journal. pone. 0066627

172. Litonjua AA, Carey VJ, Laranjo N, Harshfield BJ, McElrath TF, O'Connor GT, et al. Effect of prenatal supplementation with vitamin $\mathrm{d}$ on asthma or recurrent wheezing in offspring by age 3 years: the VDAART randomized clinical trial. JAMA (2016) 315(4):362-70. doi:10.1001/jama.2015.18589

173. Chawes BL, Bonnelykke K, Stokholm J, Vissing NH, Bjarnadottir E, Schoos AM, et al. Effect of vitamin D3 supplementation during pregnancy on risk of persistent wheeze in the offspring: a randomized clinical trial. JAMA (2016) 315(4):353-61. doi:10.1001/jama.2015.18318

174. Yepes-Nunez JJ, Brozek JL, Fiocchi A, Pawankar R, Cuello-Garcia C, Zhang Y, et al. Vitamin D supplementation in primary allergy prevention: systematic review of randomized and non-randomized studies. Allergy (2017). doi:10.1111/all.13241

175. Semba RD, Miotti PG, Chiphangwi JD, Dallabetta G, Yang LP, Saah A, et al. Maternal vitamin A deficiency and infant mortality in Malawi. J Trop Pediatr (1998) 44(4):232-4. doi:10.1093/tropej/44.4.232

176. Christian P, West KP Jr, Khatry SK, LeClerq SC, Kimbrough-Pradhan E, Katz J, et al. Maternal night blindness increases risk of mortality in the first 6 months of life among infants in Nepal. J Nutr (2001) 131(5):1510-2.

177. McCauley ME, van den Broek N, Dou L, Othman M. Vitamin A supplementation during pregnancy for maternal and newborn outcomes. Cochrane Database Syst Rev (2015) 10:CD008666. doi:10.1002/14651858.CD008666. pub3

178. Palmer AC, Schulze KJ, Khatry SK, De Luca LM, West KP Jr. Maternal vitamin A supplementation increases natural antibody concentrations of preadolescent offspring in rural Nepal. Nutrition (2015) 31(6):813-9. doi:10.1016/j.nut.2014.11.016

179. McArdle HJ, Lang C, Hayes H, Gambling L. Role of the placenta in regulation of fetal iron status. Nutr Rev (2011) 69(Suppl 1):S17-22. doi:10.1111/j.1753-4887.2011.00428.x

180. Young MF, Griffin I, Pressman E, McIntyre AW, Cooper E, McNanley T, et al. Maternal hepcidin is associated with placental transfer of iron derived from dietary heme and nonheme sources. J Nutr (2012) 142(1):33-9. doi:10.3945/ jn.111.145961

181. Singla PN, Tyagi M, Shankar R, Dash D, Kumar A. Fetal iron status in maternal anemia. Acta Paediatr (1996) 85(11):1327-30. doi:10.1111/j.1651-2227.1996. tb13919.x

182. Pena-Rosas JP, De-Regil LM, Garcia-Casal MN, Dowswell T. Daily oral iron supplementation during pregnancy. Cochrane Database Syst Rev (2015) 7:CD004736. doi:10.1002/14651858.CD004736.pub5

183. Pena-Rosas JP, De-Regil LM, Gomez Malave H, Flores-Urrutia MC, Dowswell T. Intermittent oral iron supplementation during pregnancy. Cochrane Database Syst Rev (2015) 10:CD009997. doi:10.1002/14651858. CD009997.pub2

184. Brabin L, Brabin BJ, Gies S. Influence of iron status on risk of maternal or neonatal infection and on neonatal mortality with an emphasis on developing countries. Nutr Rev (2013) 71(8):528-40. doi:10.1111/nure.12049

185. Lassi ZS, Salam RA, Haider BA, Bhutta ZA. Folic acid supplementation during pregnancy for maternal health and pregnancy outcomes. Cochrane Database Syst Rev (2013) 3:CD006896. doi:10.1002/14651858.CD006896. pub2

186. McStay CL, Prescott SL, Bower C, Palmer DJ. Maternal folic acid supplementation during pregnancy and childhood allergic disease outcomes: a question of timing? Nutrients (2017) 9(2). doi:10.3390/nu9020123

187. Rogne T, Tielemans MJ, Chong MF, Yajnik CS, Krishnaveni GV, Poston L, et al. Associations of maternal vitamin B12 concentration in pregnancy with the risks of preterm birth and low birth weight: a systematic review and 
meta-analysis of individual participant data. Am J Epidemiol (2017) 185(3): 212-23. doi:10.1093/aje/kww212

188. Siddiqua TJ, Ahmad SM, Ahsan KB, Rashid M, Roy A, Rahman SM, et al. Vitamin B12 supplementation during pregnancy and postpartum improves B12 status of both mothers and infants but vaccine response in mothers only: a randomized clinical trial in Bangladesh. Eur J Nutr (2016) 55(1):281-93. doi:10.1007/s00394-015-0845-x

189. Salam RA, Zuberi NF, Bhutta ZA. Pyridoxine (vitamin B6) supplementation during pregnancy or labour for maternal and neonatal outcomes. Cochrane Database Syst Rev (2015) 6:CD000179. doi:10.1002/14651858.CD000179. pub3

190. Dror DK, Allen LH. Interventions with vitamins B6, B12 and C in pregnancy. Paediatr Perinat Epidemiol (2012) 26(Suppl 1):55-74. doi:10.1111/ j.1365-3016.2012.01277.x

191. Bates CJ, Flewitt A, Prentice AM, Lamb WH, Whitehead RG. Efficacy of a riboflavin supplement given at fortnightly intervals to pregnant and lactating women in rural Gambia. Hum Nutr Clin Nutr (1983) 37(6):427-32.

192. West CE, Dunstan J, McCarthy S, Metcalfe J, D’Vaz N, Meldrum S, et al. Associations between maternal antioxidant intakes in pregnancy and infant allergic outcomes. Nutrients (2012) 4(11):1747-58. doi:10.3390/nu4111747

193. Maslova E, Hansen S, Strom M, Halldorsson TI, Olsen SF. Maternal intake of vitamins $\mathrm{A}, \mathrm{E}$ and $\mathrm{K}$ in pregnancy and child allergic disease: a longitudinal study from the Danish National Birth Cohort. Br J Nutr (2014) 111(6):1096108. doi: $10.1017 /$ S0007114513003395

194. Allan KM, Prabhu N, Craig LC, McNeill G, Kirby B, McLay J, et al. Maternal vitamin $\mathrm{D}$ and $\mathrm{E}$ intakes during pregnancy are associated with asthma in children. Eur Respir J (2015) 45(4):1027-36. doi:10.1183/09031936.00102214

195. Greenough A, Shaheen SO, Shennan A, Seed PT, Poston L. Respiratory outcomes in early childhood following antenatal vitamin C and E supplementation. Thorax (2010) 65(11):998-1003. doi:10.1136/thx.2010.139915

196. Dylewski ML, Mastro AM, Picciano MF. Maternal selenium nutrition and neonatal immune system development. Biol Neonate (2002) 82(2):122-7. doi: $10.1159 / 000063088$

197. Varsi K, Bolann B, Torsvik I, Rosvold Eik TC, Hol PJ, Bjorke-Monsen AL. Impact of maternal selenium status on infant outcome during the first 6 months of life. Nutrients (2017) 9(5). doi:10.3390/nu9050486

198. Kupka R, Mugusi F, Aboud S, Msamanga GI, Finkelstein JL, Spiegelman D, et al. Randomized, double-blind, placebo-controlled trial of selenium supplements among HIV-infected pregnant women in Tanzania: effects on maternal and child outcomes. Am J Clin Nutr (2008) 87(6):1802-8.

199. Rumbold A, Ota E, Nagata C, Shahrook S, Crowther CA. Vitamin C supplementation in pregnancy. Cochrane Database Syst Rev (2015) 9:CD004072. doi:10.1002/14651858.CD004072.pub3

200. Rumbold A, Ota E, Hori H, Miyazaki C, Crowther CA. Vitamin E supplementation in pregnancy. Cochrane Database Syst Rev (2015) 9:CD004069. doi:10.1002/14651858.CD004069.pub3

201. Kashanian M, Hadizadeh H, Faghankhani M, Nazemi M, Sheikhansari N. Evaluating the effects of copper supplement during pregnancy on premature rupture of membranes and pregnancy outcome. J Matern Fetal Neonatal Med (2018) 31(1):39-46. doi:10.1080/14767058.2016.1274299

202. Allen LH. Micronutrient research, programs, and policy: from meta-analyses to metabolomics. Adv Nutr (2014) 5(3):344S-51S. doi:10.3945/an.113.005421

203. Haider BA, Bhutta ZA. Multiple-micronutrient supplementation for women during pregnancy. Cochrane Database Syst Rev (2017) 4:CD004905. doi:10.1002/14651858.CD004905.pub5

204. Devakumar D, Fall CH, Sachdev HS, Margetts BM, Osmond C, Wells JC, et al. Maternal antenatal multiple micronutrient supplementation for longterm health benefits in children: a systematic review and meta-analysis. $B M C$ Med (2016) 14:90. doi:10.1186/s12916-016-0633-3

205. Moore SE, Fulford AJ, Darboe MK, Jobarteh ML, Jarjou LM, Prentice AM. A randomized trial to investigate the effects of pre-natal and infant nutritional supplementation on infant immune development in rural Gambia: the ENID trial: early nutrition and immune development. BMC Pregnancy Childbirth (2012) 12:107. doi:10.1186/1471-2393-12-107

206. Gibson GR, Roberfroid MB. Dietary modulation of the human colonic microbiota: introducing the concept of prebiotics. J Nutr (1995) 125(6):1401-12.

207. Schultz M, Gottl C, Young RJ, Iwen P, Vanderhoof JA. Administration of oral probiotic bacteria to pregnant women causes temporary infantile colonization. J Pediatr Gastroenterol Nutr (2004) 38(3):293-7. doi:10.1097/00005176-200403000-00012
208. Gueimonde M, Sakata S, Kalliomaki M, Isolauri E, Benno Y, Salminen S. Effect of maternal consumption of lactobacillus GG on transfer and establishment of fecal bifidobacterial microbiota in neonates. J Pediatr Gastroenterol Nutr (2006) 42(2):166-70. doi:10.1097/01.mpg.0000189346.25172.fd

209. Lahtinen SJ, Boyle RJ, Kivivuori S, Oppedisano F, Smith KR, Robins-Browne R, et al. Prenatal probiotic administration can influence Bifidobacterium microbiota development in infants at high risk of allergy. J Allergy Clin Immunol (2009) 123(2):499-501. doi:10.1016/j.jaci.2008.11.034

210. Grzeskowiak L, Gronlund MM, Beckmann C, Salminen S, von Berg A, Isolauri $\mathrm{E}$. The impact of perinatal probiotic intervention on gut microbiota: double-blind placebo-controlled trials in Finland and Germany. Anaerobe (2012) 18(1):7-13. doi:10.1016/j.anaerobe.2011.09.006

211. Ortiz-Andrellucchi A, Sanchez-Villegas A, Rodriguez-Gallego C, Lemes A, Molero T, Soria A, et al. Immunomodulatory effects of the intake of fermented milk with Lactobacillus casei DN114001 in lactating mothers and their children. Br J Nutr (2008) 100(4):834-45. doi:10.1017/S0007114508959183

212. Boyle RJ, Mah LJ, Chen A, Kivivuori S, Robins-Browne RM, Tang ML. Effects of Lactobacillus GG treatment during pregnancy on the development of fetal antigen-specific immune responses. Clin Exp Allergy (2008) 38(12):1882-90. doi:10.1111/j.1365-2222.2008.03100.x

213. Cuello-Garcia CA, Brozek JL, Fiocchi A, Pawankar R, Yepes-Nunez JJ, Terracciano L, et al. Probiotics for the prevention of allergy: a systematic review and meta-analysis of randomized controlled trials. J Allergy Clin Immunol (2015) 136(4):952-61. doi:10.1016/j.jaci.2015.04.031

214. Azad MB, Coneys JG, Kozyrskyj AL, Field CJ, Ramsey CD, Becker AB, et al. Probiotic supplementation during pregnancy or infancy for the prevention of asthma and wheeze: systematic review and meta-analysis. BMJ (2013) 347:f6471. doi:10.1136/bmj.f6471

215. Zuccotti G, Meneghin F, Aceti A, Barone G, Callegari ML, Di Mauro A, et al. Probiotics for prevention of atopic diseases in infants: systematic review and meta-analysis. Allergy (2015) 70(11):1356-71. doi:10.1111/all.12700

216. Nauta AJ, Ben Amor K, Knol J, Garssen J, van der Beek EM. Relevance of pre- and postnatal nutrition to development and interplay between the microbiota and metabolic and immune systems. Am JClin Nutr (2013) 98(2):586S-93S. doi:10.3945/ajcn.112.039644

217. Kukkonen K, Savilahti E, Haahtela T, Juntunen-Backman K, Korpela R, Poussa $\mathrm{T}$, et al. Long-term safety and impact on infection rates of postnatal probiotic and prebiotic (synbiotic) treatment: randomized, double-blind, placebo-controlled trial. Pediatrics (2008) 122(1):8-12. doi:10.1542/ peds.2007-1192

218. Andreas NJ, Kampmann B, Mehring Le-Doare K. Human breast milk: a review on its composition and bioactivity. Early Hum Dev (2015) 91(11):629-35. doi:10.1016/j.earlhumdev.2015.08.013

219. Lawrence RM, Pane CA. Human breast milk: current concepts of immunology and infectious diseases. Curr Probl Pediatr Adolesc Health Care (2007) 37(1):7-36. doi:10.1016/j.cppeds.2006.10.002

220. Oddy WH. A review of the effects of breastfeeding on respiratory infections, atopy, and childhood asthma. J Asthma (2004) 41(6):605-21. doi:10.1081/ JAS-200026402

221. Ballard O, Morrow AL. Human milk composition: nutrients and bioactive factors. Pediatr Clin North Am (2013) 60(1):49-74. doi:10.1016/j. pcl.2012.10.002

222. Hannan MA, Faraji B, Tanguma J, Longoria N, Rodriguez RC. Maternal milk concentration of zinc, iron, selenium, and iodine and its relationship to dietary intakes. Biol Trace Elem Res (2009) 127(1):6-15. doi:10.1007/s12011-008-8221-9

223. Mahdavi R, Nikniaz L, Gayemmagami SJ. Association between zinc, copper, and iron concentrations in breast milk and growth of healthy infants in Tabriz, Iran. Biol Trace Elem Res (2010) 135(1-3):174-81. doi:10.1007/ s12011-009-8510-y

224. Yuhas R, Pramuk K, Lien EL. Human milk fatty acid composition from nine countries varies most in DHA. Lipids (2006) 41(9):851-8. doi:10.1007/ s11745-006-5040-7

225. Brenna JT, Diau GY. The influence of dietary docosahexaenoic acid and arachidonic acid on central nervous system polyunsaturated fatty acid composition. Prostaglandins Leukot Essent Fatty Acids (2007) 77(5-6):247-50. doi:10.1016/j.plefa.2007.10.016

226. Ahmad SM, Hossain MI, Bergman P, Kabir Y, Raqib R. The effect of postpartum vitamin A supplementation on breast milk immune regulators and infant immune functions: study protocol of a randomized, controlled trial. Trials (2015) 16:129. doi:10.1186/s13063-015-0654-9 
227. Underwood BA. Maternal vitamin A status and its importance in infancy and early childhood. Am J Clin Nutr (1994) 59(2 Suppl):517S-22S.

228. Butte NF, Calloway DH. Evaluation of lactational performance of Navajo women. Am J Clin Nutr (1981) 34(10):2210-5.

229. Ajans ZA, Sarrif A, Husbands M. Inluence of vitamin A on human colostrum and early milk. Am J Clin Nutr (1965) 17(3):139-42.

230. Oliveira JM, Allert R, East CE. Vitamin A supplementation for postpartum women. Cochrane Database Syst Rev (2016) 3:CD005944. doi:10.1002/14651858.CD005944.pub3

231. Gogia S, Sachdev HS. Vitamin A supplementation for the prevention of morbidity and mortality in infants six months of age or less. Cochrane Database Syst Rev (2011) 10:CD007480. doi:10.1002/14651858.CD007480.pub2

232. Sneed SM, Zane C, Thomas MR. The effects of ascorbic acid, vitamin B6, vitamin B12, and folic acid supplementation on the breast milk and maternal nutritional status of low socioeconomic lactating women. Am J Clin Nutr (1981) 34(7):1338-46.

233. Kovacs CS. Vitamin D in pregnancy and lactation: maternal, fetal, and neonatal outcomes from human and animal studies. Am J Clin Nutr (2008) 88(2):520S-8S.

234. Hollis BW, Wagner CL. Vitamin D requirements during lactation: highdose maternal supplementation as therapy to prevent hypovitaminosis D for both the mother and the nursing infant. Am J Clin Nutr (2004) 80 (6 Suppl):1752S-8S.

235. Oberhelman SS, Meekins ME, Fischer PR, Lee BR, Singh RJ, Cha SS, et al. Maternal vitamin D supplementation to improve the vitamin D status of breast-fed infants: a randomized controlled trial. Mayo Clin Proc (2013) 88(12):1378-87. doi:10.1016/j.mayocp.2013.09.012

236. Wheeler BJ, Taylor BJ, Herbison P, Haszard JJ, Mikhail A, Jones S, et al. Highdose monthly maternal cholecalciferol supplementation during breastfeeding affects maternal and infant vitamin D status at 5 months postpartum: a randomized controlled trial. J Nutr (2016) 146(10):1999-2006. doi:10.3945/ jn.116.236679

237. Chandy DD, Kare J, Singh SN, Agarwal A, Das V, Singh U, et al. Effect of vitamin D supplementation, directly or via breast milk for term infants, on serum 25 hydroxyvitamin $\mathrm{D}$ and related biochemistry, and propensity to infection: a randomised placebo-controlled trial. Br J Nutr (2016) 116(1):52-8. doi:10.1017/S0007114516001756

238. Basile LA, Taylor SN, Wagner CL, Horst RL, Hollis BW. The effect of high-dose vitamin D supplementation on serum vitamin D levels and milk calcium concentration in lactating women and their infants. Breastfeed Med (2006) 1(1):27-35. doi:10.1089/bfm.2006.1.27

239. Allen LH. B vitamins in breast milk: relative importance of maternal status and intake, and effects on infant status and function. Adv Nutr (2012) 3(3):362-9. doi:10.3945/an.111.001172

240. Kumpulainen J, Salmenpera L, Siimes MA, Koivistoinen P, Perheentupa J. Selenium status of exclusively breast-fed infants as influenced by maternal organic or inorganic selenium supplementation. Am JClin Nutr (1985) 42(5):829-35.

241. Trafikowska U, Sobkowiak E, Butler JA, Whanger PD, Zachara BA. Organic and inorganic selenium supplementation to lactating mothers increase the blood and milk Se concentrations and Se intake by breastfed infants. J Trace Elem Med Biol (1998) 12(2):77-85. doi:10.1016/ S0946-672X(98)80029-1

242. Flax VL, Bentley ME, Combs GF Jr, Chasela CS, Kayira D, Tegha G, et al. Plasma and breast-milk selenium in HIV-infected Malawian mothers are positively associated with infant selenium status but are not associated with maternal supplementation: results of the Breastfeeding, Antiretrovirals, and Nutrition study. Am J Clin Nutr (2014) 99(4):950-6. doi:10.3945/ ajcn. 113.073833

243. Dorea JG. Selenium and breast-feeding. Br J Nutr (2002) 88(5):443-61. doi:10.1079/BJN2002692

244. Innis SM. Impact of maternal diet on human milk composition and neurological development of infants. Am J Clin Nutr (2014) 99(3):734S-41S. doi:10.3945/ajen.113.072595

245. Richard C, Lewis ED, Field CJ. Evidence for the essentiality of arachidonic and docosahexaenoic acid in the postnatal maternal and infant diet for the development of the infant's immune system early in life. Appl Physiol Nutr Metab (2016) 41(5):461-75. doi:10.1139/apnm-2015-0660
246. Duchen K, Yu G, Bjorksten B. Atopic sensitization during the first year of life in relation to long chain polyunsaturated fatty acid levels in human milk. Pediatr Res (1998) 44(4):478-84. doi:10.1203/00006450-199810000-00003

247. Duchen K, Casas R, Fageras-Bottcher M, Yu G, Bjorksten B. Human milk polyunsaturated long-chain fatty acids and secretory immunoglobulin A antibodies and early childhood allergy. Pediatr Allergy Immunol (2000) 11(1):29-39. doi:10.1034/j.1399-3038.2000.00052.x

248. Reichardt P, Muller D, Posselt U, Vorberg B, Diez U, Schlink U, et al. Fatty acids in colostrum from mothers of children at high risk of atopy in relation to clinical and laboratory signs of allergy in the first year of life. Allergy (2004) 59(4):394-400. doi:10.1111/j.1398-9995.2003.00429.x

249. Stoney RM, Woods RK, Hosking CS, Hill DJ, Abramson MJ, Thien FC. Maternal breast milk long-chain n-3 fatty acids are associated with increased risk of atopy in breastfed infants. Clin Exp Allergy (2004) 34(2):194-200. doi:10.1111/j.1365-2222.2004.01852.x

250. Lauritzen L, Kjaer TM, Fruekilde MB, Michaelsen KF, Frokiaer H. Fish oil supplementation of lactating mothers affects cytokine production in 2 1/2-year-old children. Lipids (2005) 40(7):669-76. doi:10.1007/s11745005-1429-6

251. Field CJ, Clandinin MT, Van Aerde JE. Polyunsaturated fatty acids and T-cell function: implications for the neonate. Lipids (2001) 36(9):1025-32. doi:10.1007/s11745-001-0813-6

252. Calder PC. Immunomodulation by omega-3 fatty acids. Prostaglandins Leukot Essent Fatty Acids (2007) 77(5-6):327-35. doi:10.1016/j.plefa.2007.10.015

253. Baldassarre ME, Di Mauro A, Mastromarino P, Fanelli M, Martinelli D, Urbano F, et al. Administration of a multi-strain probiotic product to women in the perinatal period differentially affects the breast milk cytokine profile and may have beneficial effects on neonatal gastrointestinal functional symptoms. A randomized clinical trial. Nutrients (2016) 8(11):677. doi:10.3390/ nu8110677

254. Vitali B, Cruciani F, Baldassarre ME, Capursi T, Spisni E, Valerii MC, et al. Dietary supplementation with probiotics during late pregnancy: outcome on vaginal microbiota and cytokine secretion. BMC Microbiol (2012) 12:236. doi:10.1186/1471-2180-12-236

255. Sohn K, Underwood MA. Prenatal and postnatal administration of prebiotics and probiotics. Semin Fetal Neonatal Med (2017) 22(5):284-9. doi:10.1016/j. siny.2017.07.002

256. Rautava S, Luoto R, Salminen S, Isolauri E. Microbial contact during pregnancy, intestinal colonization and human disease. Nat Rev Gastroenterol Hepatol (2012) 9(10):565-76. doi:10.1038/nrgastro.2012.144

257. Osendarp SJ, Santosham M, Black RE, Wahed MA, van Raaij JM, Fuchs GJ. Effect of zinc supplementation between 1 and 6 mo of life on growth and morbidity of Bangladeshi infants in urban slums. Am JClin Nutr (2002) 76(6):1401-8.

258. Sazawal S, Black RE, Ramsan M, Chwaya HM, Dutta A, Dhingra U, et al. Effect of zinc supplementation on mortality in children aged 1-48 months: a community-based randomised placebo-controlled trial. Lancet (2007) 369(9565):927-34. doi:10.1016/S0140-6736(07)60452-8

259. Tielsch JM, Khatry SK, Stoltzfus RJ, Katz J, LeClerq SC, Adhikari R, et al. Effect of daily zinc supplementation on child mortality in southern Nepal: a community-based, cluster randomised, placebo-controlled trial. Lancet (2007) 370(9594):1230-9. doi:10.1016/S0140-6736(07)61539-6

260. Brooks WA, Santosham M, Roy SK, Faruque AS, Wahed MA, Nahar K, et al. Efficacy of zinc in young infants with acute watery diarrhea. Am J Clin Nutr (2005) 82(3):605-10.

261. Fischer Walker CL, Bhutta ZA, Bhandari N, Teka T, Shahid F, Taneja S, et al. Zinc supplementation for the treatment of diarrhea in infants in Pakistan, India and Ethiopia. J Pediatr Gastroenterol Nutr (2006) 43(3):357-63. doi:10.1097/01.mpg.0000232018.40907.00

262. Bhatnagar S, Wadhwa N, Aneja S, Lodha R, Kabra SK, Natchu UC, et al. Zinc as adjunct treatment in infants aged between 7 and 120 days with probable serious bacterial infection: a randomised, double-blind, placebo-controlled trial. Lancet (2012) 379(9831):2072-8. doi:10.1016/S0140-6736(12)60477-2

263. Wadhwa N, Basnet S, Natchu UCM, Shrestha LP, Bhatnagar S, Sommerfelt H, et al. Zinc as an adjunct treatment for reducing case fatality due to clinical severe infection in young infants: study protocol for a randomized controlled trial. BMC Pharmacol Toxicol (2017) 18(1):56. doi:10.1186/ s40360-017-0162-5 
264. Habib MA, Soofi S, Sheraz A, Bhatti ZS, Okayasu H, Zaidi SZ, et al. Zinc supplementation fails to increase the immunogenicity of oral poliovirus vaccine: a randomized controlled trial. Vaccine (2015) 33(6):819-25. doi:10.1016/j. vaccine.2014.12.001

265. Banupriya N, Vishnu Bhat B, Benet BD, Sridhar MG, Parija SC. Efficacy of zinc supplementation on serum calprotectin, inflammatory cytokines and outcome in neonatal sepsis - a randomized controlled trial. J Matern Fetal Neonatal Med (2017) 30(13):1627-31. doi:10.1080/14767058.2016. 1220524

266. Allen KJ, Panjari M, Koplin JJ, Ponsonby AL, Vuillermin P, Gurrin LC, et al. VITALITY trial: protocol for a randomised controlled trial to establish the role of postnatal vitamin D supplementation in infant immune health. BMJ Open (2015) 5(12):e009377. doi:10.1136/bmjopen-2015-009377

267. Haider BA, Sharma R, Bhutta ZA. Neonatal vitamin A supplementation for the prevention of mortality and morbidity in term neonates in low and middle income countries. Cochrane Database Syst Rev (2017) 2:CD006980. doi:10.1002/14651858.CD006980.pub3

268. Benn CS, Rodrigues A, Yazdanbakhsh M, Fisker AB, Ravn H, Whittle H, et al. The effect of high-dose vitamin A supplementation administered with BCG vaccine at birth may be modified by subsequent DTP vaccination. Vaccine (2009) 27(21):2891-8. doi:10.1016/j.vaccine.2009.02.080

269. Benn CS, Aaby P, Arts RJ, Jensen KJ, Netea MG, Fisker AB. An enigma: why vitamin A supplementation does not always reduce mortality even though vitamin A deficiency is associated with increased mortality. Int J Epidemiol (2015) 44(3):906-18. doi:10.1093/ije/dyv117

270. Diness BR, Fisker AB, Roth A, Yazdanbakhsh M, Sartono E, Whittle H, et al. Effect of high-dose vitamin A supplementation on the immune response to Bacille Calmette-Guerin vaccine. Am J Clin Nutr (2007) 86(4):1152-9.

271. Jorgensen MJ, Fisker AB, Sartono E, Andersen A, Erikstrup C, Lisse IM, et al. The effect of at-birth vitamin A supplementation on differential leucocyte counts and in vitro cytokine production: an immunological study nested within a randomised trial in Guinea-Bissau. Br J Nutr (2013) 109(3):467-77. doi:10.1017/S0007114512001304

272. McDonald SL, Savy M, Fulford AJ, Kendall L, Flanagan KL, Prentice AM. A double blind randomized controlled trial in neonates to determine the effect of vitamin A supplementation on immune responses: the Gambia protocol. BMC Pediatr (2014) 14:92. doi:10.1186/1471-2431-14-92

273. Barry DM, Reeve AW. Increased incidence of gram-negative neonatal sepsis with intramuscula iron administration. Pediatrics (1977) 60(6):908-12.

274. Levine RL, Lemons JA. Letter: concentrations of serum iron in relation to infection in the neonate. J Pediatr (1975) 87(2):331-2. doi:10.1016/ S0022-3476(75)80626-3

275. Becroft DM, Dix MR, Farmer K. Intramuscular iron-dextran and susceptibility of neonates to bacterial infections. In vitro studies. Arch Dis Child (1977) 52(10):778-81. doi:10.1136/adc.52.10.778

276. Domellof M, Cohen RJ, Dewey KG, Hernell O, Rivera LL, Lonnerdal B. Iron supplementation of breast-fed Honduran and Swedish infants from 4 to 9 months of age. J Pediatr (2001) 138(5):679-87. doi:10.1067/mpd.2001.112895

277. Cross JH, Bradbury RS, Fulford AJ, Jallow AT, Wegmuller R, Prentice AM, et al. Oral iron acutely elevates bacterial growth in human serum. Sci Rep (2015) 5:16670. doi:10.1038/srep16670

278. Gwamaka M, Kurtis JD, Sorensen BE, Holte S, Morrison R, Mutabingwa TK, et al. Iron deficiency protects against severe Plasmodium falciparum malaria and death in young children. Clin Infect Dis (2012) 54(8):1137-44. doi:10.1093/cid/cis010

279. Szabo M, Vasarhelyi B, Balla G, Szabo T, Machay T, Tulassay T. Acute postnatal increase of extracellular antioxidant defence of neonates: the role of iron metabolism. Acta Paediatr (2001) 90(10):1167-70. doi:10.111 1/j.1651-2227.2001.tb03248.x

280. Sturgeon P. Studies of iron requirements in infante and children. I. Normal values for serum iron, copper and free erythrocyte protoporphyrin. Pediatrics (1954) 13(2):107-25.

281. Tarnow-Mordi W, Isaacs D, Dutta S. Adjunctive immunologic interventions in neonatal sepsis. Clin Perinatol (2010) 37(2):481-99. doi:10.1016/j. clp.2009.12.002

282. Manzoni P, Rinaldi M, Cattani S, Pugni L, Romeo MG, Messner H, et al. Bovine lactoferrin supplementation for prevention of late-onset sepsis in very low-birth-weight neonates: a randomized trial. JAMA (2009) 302(13):1421-8. doi:10.1001/jama.2009.1403

283. Pammi M, Suresh G. Enteral lactoferrin supplementation for prevention of sepsis and necrotizing enterocolitis in preterm infants. Cochrane Database Syst Rev (2017) 6:CD007137. doi:10.1002/14651858.CD007137.pub5

284. Mills RJ, Davies MW. Enteral iron supplementation in preterm and low birth weight infants. Cochrane Database Syst Rev (2012) 3:CD005095. doi:10.1002/14651858.CD005095.pub2

285. Long H, Yi JM, Hu PL, Li ZB, Qiu WY, Wang F, et al. Benefits of iron supplementation for low birth weight infants: a systematic review. BMC Pediatr (2012) 12:99. doi:10.1186/1471-2431-12-99

286. Aggarwal R, Gathwala G, Yadav S, Kumar P. Selenium supplementation for prevention of late-onset sepsis in very low birth weight preterm neonates. J Trop Pediatr (2016) 62(3):185-93. doi:10.1093/tropej/fmv096

287. Darlow BA, Austin NC. Selenium supplementation to prevent short-term morbidity in preterm neonates. Cochrane Database Syst Rev (2003) 4:CD003312. doi:10.1002/14651858.CD003312

288. Underwood MA. Impact of probiotics on necrotizing enterocolitis. Semin Perinatol (2017) 41(1):41-51. doi:10.1053/j.semperi.2016.09.017

289. AlFaleh K, Anabrees J. Probiotics for prevention of necrotizing enterocolitis in preterm infants. Evid Based Child Health (2014) 9(3):584-671. doi:10.1002/ ebch. 1976

290. Sawh SC, Deshpande S, Jansen S, Reynaert CJ, Jones PM. Prevention of necrotizing enterocolitis with probiotics: a systematic review and meta-analysis. PeerJ (2016) 4:e2429. doi:10.7717/peerj.2429

291. Chang HY, Chen JH, Chang JH, Lin HC, Lin CY, Peng CC. Multiple strains probiotics appear to be the most effective probiotics in the prevention of necrotizing enterocolitis and mortality: an updated meta-analysis. PLoS One (2017) 12(2):e0171579. doi:10.1371/journal.pone.0171579

292. Srinivasjois R, Rao S, Patole S. Prebiotic supplementation in preterm neonates: updated systematic review and meta-analysis of randomised controlled trials. Clin Nutr (2013) 32(6):958-65. doi:10.1016/j.clnu.2013.05.009

293. Osborn DA, Sinn JK. Prebiotics in infants for prevention of allergy. Cochrane Database Syst Rev (2013) 3:CD006474. doi:10.1002/14651858.CD006474. pub3

294. Braegger C, Chmielewska A, Decsi T, Kolacek S, Mihatsch W, Moreno L, et al. Supplementation of infant formula with probiotics and/or prebiotics: a systematic review and comment by the ESPGHAN committee on nutrition. J Pediatr Gastroenterol Nutr (2011) 52(2):238-50. doi:10.1097/ MPG.0b013e3181fb9e80

295. Szajewska H, Guarino A, Hojsak I, Indrio F, Kolacek S, Shamir R, et al. Use of probiotics for management of acute gastroenteritis: a position paper by the ESPGHAN Working Group for Probiotics and Prebiotics. J Pediatr GastroenterolNutr (2014) 58(4):531-9. doi:10.1097/MPG.0000000000000320

296. Panigrahi P, Parida S, Nanda NC, Satpathy R, Pradhan L, Chandel DS, et al. A randomized synbiotic trial to prevent sepsis among infants in rural India. Nature (2017) 548(7668):407-12. doi:10.1038/nature23480

297. West KP Jr, Katz J, Khatry SK, LeClerq SC, Pradhan EK, Shrestha SR, et al. Double blind, cluster randomised trial of low dose supplementation with vitamin A or beta carotene on mortality related to pregnancy in Nepal. The NNIPS-2 Study Group. BMJ (1999) 318(7183):570-5.

298. Kirkwood BR, Hurt L, Amenga-Etego S, Tawiah C, Zandoh C, Danso S, et al. Effect of vitamin A supplementation in women of reproductive age on maternal survival in Ghana (ObaapaVitA): a cluster-randomised, placebo-controlled trial. Lancet (2010) 375(9726):1640-9. doi:10.1016/ S0140-6736(10)60311-X

299. West KP Jr, Christian P, Labrique AB, Rashid M, Shamim AA, Klemm RD, et al. Effects of vitamin A or beta carotene supplementation on pregnancy-related mortality and infant mortality in rural Bangladesh: a cluster randomized trial. JAMA (2011) 305(19):1986-95. doi:10.1001/jama.2011.656

300. Haider BA, Bhutta ZA. Multiple-micronutrient supplementation for women during pregnancy. Cochrane Database Syst Rev (2015) 11:CD004905. doi:10.1002/14651858.CD004905.pub4

301. Goldenberg RL. The plausibility of micronutrient deficiency in relationship to perinatal infection. J Nutr (2003) 133(5 Suppl 2):1645S-8S.

302. Chandra RK. Excessive intake of zinc impairs immune responses. JAMA (1984) 252(11):1443-6. doi:10.1001/jama.1984.03350110043027 
303. Fiocchi A, Pawankar R, Cuello-Garcia C, Ahn K, Al-Hammadi S, Agarwal A, et al. World allergy organization-mcmaster university guidelines for allergic disease prevention (GLAD-P): probiotics. World Allergy Organ J (2015) 8(1):4. doi:10.1186/s40413-015-0055-2

Conflict of Interest Statement: The author declares that the research was conducted in the absence of any commercial or financial relationships that could be construed as a potential conflict of interest.
The reviewer DM and handling editor declared their shared affiliation.

Copyright (C) 2017 Prentice. This is an open-access article distributed under the terms of the Creative Commons Attribution License (CC BY). The use, distribution or reproduction in other forums is permitted, provided the original author(s) or licensor are credited and that the original publication in this journal is cited, in accordance with accepted academic practice. No use, distribution or reproduction is permitted which does not comply with these terms. 